\title{
SIMULASI VARIASI JUMLAH DAN PERIODE INVESTASI DALAM MODEL PROFIT-LOSS SHARING DENGAN DANA TABARRU'
}

\author{
Wahyuning Murniati \\ wahyuning123@gmail.com \\ N ovriana Sumarti \\ FMIPA Institut Teknologi Bandung
}

\begin{abstract}
Profit and loss sharing model is one form of investment scheme is considerated Islamic finance. The borrower of the investment fund and investors should be in a fair sharing of both profit and losses earned in the investment process. The model used in this paper is the modification of previous research in which the investor gives an investment fund to some low-income traders in tradisional market. The traders will give back the fund with some portion of profit if the financial condition is good. That is the profit sharing scheme. In order to define loss sharing explicitly, in this paper we add tabarru' fund in the model by applying the principle of net insurance premiums. T abarru' fund is collection funds of the trader and when loss occurs, the trader will get the fund back as a ben efit. Futhermore, this model is implemented in the daily net profit of a tradisional market trader in Bandung on variation of capital and period investment. From the result, it can be concluded that the application of tabarru' fund provide higher profit more than previous model.
\end{abstract}

Key words: profit and loss sharing model, tabarru' fund, syari'ah investment model, Islamic finance, insurance

\section{ABSTRAK}

Model profit and loss sharing merupakan salah satu bentuk sistem investasi yang diterapkan dalam keuangan Islam. Penerima investasi dan investor melakukan pembagian keuntungan dan kerugian secara adil. Model yang digunakan dalam jurnal ini merupakan modifikasi dari penelitian sebelumnya dimana investor memberikan modal kepada pedagang berpenghasilan rendah di pasar tradisional. Pedagang akan mengembalikan modal tersebut dengan tambahan bagi hasil ketika pedagang mengalami keuntungan. Dalam jurnal ini, dilakukan penambahan dana tabarru' dalam model dengan menggunakan prinsip premi bersih dalam asuransi. Dana tabarru' merupakan kumpulan dana yang berasal dari pedagang dimana jika terjadi kerugian maka pedagang akan mendapatkan dana itu kembali sebagai santunan. Selanjutnya, model ini diimplementasi kan pada laba bersi h harian pedagang di suatu pasar tradisional Bandung pada variasi jumlah dan periodeinvestasi. Dari hasil yang didapat, disimpulkan bahwa penerapan dana tabarru' memberikan keuntungan yang lebih besar daripada model investasi sebelumnya.

Kata kunci: model bagi hasil, dana tabarru', model investasi syari'ah, keuangan Islam, asuransi

\section{PENDAHULUAN}

Pertumbuhan ekonomi berdampak pada semakin terpinggirnya keberadaan pasar tradisional seiring dengan berkembangnya pasar modern. Konsumen lebih memilih pasar modern yang memberikan jaminan kualitas produk tinggi dan pelayanan konsumen yang lebih baik daripada pasar tradisional, oleh Karena itu, pedagang pasar tradisional perlu melakukan inovasi untuk menarik lebih banyak konsumen sehingga membutuhkan modal tambahan. Disisi lain, bank konvensional di Indonesia telah meluncurkan berbagai program kredit untuk usaha kecil yang sebenarnya bisa dimanfaatkan oleh pe dagang pasar tradisional, namun, pada praktek penyaluran dananya masih kurang 
menyeluruh dan persyaratan yang harus dipenuhi tergolong rumit. Hal inilah yang membuat para pedagang pasar tradisional lebih memilih jasa rentenir untuk mendapatkan modal tambahan dengan proses cepat dan mudah.

Sebagaimana yang kita ketahui bahwa sistem investasi rentenir menetapkan suku bunga yang relatif tinggi tanpa mempedulikan keadaan pedagang, begitupun juga bank konvensional. Keadaaan untung maupun rugi yang didapatkan, pedagang memiliki kewajiban untuk membayar angsuran pokok yang telah ditentukan dengan pemberian denda untuk setiap keterlambatan. $\mathrm{Hal}$ ini tentu saja merugikan pihak peminjam dan menguntungkan pemberi pinjaman. Sesuai dengan konsep bagi hasil syari'ah dimana seharusnya ada keadilan dalam system investasi maka hal ini dilarang dalam Islam. Sebagaimana yang tertera dalam QS.ar-Rum: 39 yang berarti: “A pa-apa yang kamu berikan (berupa pinjaman) dalam bentuk riba agar harta manusia bertambah, maka hal itu tidak bertambah di sisi Allah", oleh karena itu diperlukan suatu system investasi yang adil dan sesuai dengan syariat Islam.

Sekarang ini konsep keuangan berbasis syariat Islam telah tumbuh menjadi suatu trend pada perekonomian dunia, termasuk juga di Indonesia. Berdasarkan data perbankan syari'ah Indonesia (Direktorat Perbankan Syari'ah, 2011), pertumbuhan bank konvensional lebih kecil daripada bank syari'ah dimana bank syari'ah yang mengalami pertumbuhan relative sekitar $40 \%$ per tahun dalam sepuluh tahun terakhir sementara bank konvensional $20 \%$. Hal ini tidak menutup kemungkinan bahwa bank konvensional akan tergeser seiring berkembangnya pertumbuhan bank syari'ah begitu pula dengan rentenir.

Terdapat beberapa penelitian terkait profit-loss sharing yang telah dilakukan sebelumnya. Misalnya pada (Sugema et al., 2010) dimana makalah ini memaparkan perbandingan antara konsep bunga dan profit-loss sharing. Pada proses disimpulkan bahwa profit-loss sharing merupakan satusatunya konsep yang memberikan keadilan bagi semua pihak terkait. Keadilan yang dimaksud merupakan keadilan dalam hal pembagian keuntungan dan kerugian hasil proses investasi. Penelitian selanjutnya menjelaskan tentang kelemahan profit-loss sharing pada prateknya. (Rahman et al, 2014) ini menjelaskan kekurangan dan kelebihan profit-loss sharing yang dievaluasi secara teoritik dengan mencari alasan mengapa terdapat kegagalan dalam praktek profit-loss sharing. Kesimpulan yang didapat adalah kekurangan profit-loss sharing dapat diatasi jika lembaga penyelenggaranya bertindak sebagai wiraswasta bukan sebagai perantara saja. A rtinya diperlukan suatu lembaga yang berdiri sendiri untuk mengelola investasi menggunakan model ini. Berbeda dengan (Ascarya, 2009) menyatakan bahwa kegagalan profit-loss sharing pada prakteknya dikarenakan terletak pada manusia pelaksananya. Analisis pada makalah ini dilakukan menggunakan metodologi A nalytic N etwork Process (ANP) pada permasalahan yang dihadapi oleh bank Islam di Indonesia. Seperti halnya pada (Dar dan Presley, 2000), menyatakan bahwa kegagalan konsep profitloss sharing dikarenakan terdapat ketidak seimbangan antara proses pengelolahan dan pengendalian pada investasi yang dilakukan oleh manusia penyelenggaranya. Berdasarkan penelitian-penelitian ini, penulis berpendapat bahwa perlu dilakukan penelitian lebih lanjut mengenai konsep profit-loss sharing.

Pada penelitian ini, penulis berupaya mengkaji pembuatan model investasi syari'ah pada penelitian sebelumnya pada (Sumarti et al, 2014, 2015). Model investasi pada makalah ini berupa pemberian kredit mikro kepada pedagang kecil dengan menerapkan konsep profit-loss sharing dengan menggunakan prinsip musyarakah. Selanjutnya, diterapkan penambahan dana tabarru' sebagai perwujudan profit-loss sharing. Penerapan dana tabarru' ini menggunakan 
prinsip premi bersih pada asuransi. Prinsip ini mengharapkan tidak ada kerugian dalam implementasi model pada laba bersih pedagang. Dengan kata lain, pembayaran dana atau premi sebanding dengan pemberian santunan kepada pedagang.

Hasil penelitian ini diharapkan memberikan kontribusi positif bagi masyarakat, tidak hanya di wilayah Bandung tetapi juga seluruh Indonesia, dalam hal investasi. Masyarakat seharusnya lebih teliti dalam pengelolahan dana usaha sehingga dapat terhindar dari praktek riba yang merugikan banyak pihak dan dilarang oleh Islam. Selain itu, hasil kajian ini diharapkan dapat mengurangi keterlibatan masyarakat dalam praktek rentenir dan meningkatkan perkembangan keuangan syari'ah di Indonesia yang memiliki penduduk mayoritas beragama Islam.

\section{TINJAUAN TEORETIS}

\section{Prinsip Investasi Syari'ah}

Investasi adalah suatu bentuk penanaman modal atau menempatan asset, baik berupa harta ataupun dana, pada sesuatu yang diharapkan dapat meningkatkan nilainya di masa depan. Menurut Iwan P. Pontjowinoto (2003) menyatakan bahwa terdapat beberapa prinsip investasi yang ditetapkan dalam Islam.

Prinsip-prinsip tersebut adalah: (1) Investasi Islam sebaiknya memberi manfaat finansial yang kompetitif dibandingkan investasi lainya; (2) Praktik investasi harus terhindar dari unsur riba, gharah, maysir dan haram. Riba secara umum berarti tambahan dana atas modal yang diproleh dengan cara yang tidah dibenarkan oleh syariat Islam. Penjelasan lebih detail mengenai riba akan diberikan pada uraian selanjutnya. Gharar dapat diartikan dengan sesuatu yang tidak diketahui antara tercapainya dan tidaknya suatu tujuan atau muncul keraguan atas wujud fisik dari objek transaksi. Maysir adalah tempat untuk memudahkan sesuatu. Dikatakan demikian karena seseorang yang seharusnya menempuh jalan sulit, akan tetapi dengan cara yang singkat dan mudah berharap mendapatkan hasil yang diinginkan. Salah satu contoh maysir adalah segala bentuk perjudian, sedangkan yang dimaksud haram adalah sesuatu yang dilarang oleh Allah SWT baik berupa zat maupun proses mendapatkanya; (3) Adanya etika perjanjian atau akad tertulis dalam melakukan transaksi; (4) Investasi Islam sebaiknya memberikan kontribusi positif bagi masyarakat dan lingkungan sekitar; (5) Kesadaran akan adanya kehidupan yang kekal setelah dunia dapat dijadikan panduan dalam melakukan praktik investasi sehingga setiap usaha yang dilakukan hendaknya didasari atas keinginan untuk mencapai keridhoan Allah SWT.

Semua prinsip ini menjadi dasar pelaksaan investasi keuangan sesuai syariat Islam.

\section{Konsep Riba}

Riba adalah kelebihan yang dipungut bersama jumlah utang yang mengandung unsur penganiayaan dan penindasan, bukan sekedar kelebihan atau penambahan uang saja (Pusat Riset dan Edukasi Bank Sentral, 2012). Penganiayaan yang dimaksud bisa berupa pelipatgandaan hutang atau lainnya. Sedangkan menurut istilah teknis, riba berarti pengambilan dari harta pokok atau modal secara bathil. Dikatakan bathil karena pemilik dana mewajibkan peminjam untuk membayar lebih dari pinjaman tanpa memperhatikan apakan hal tersebut menguntungkan atau merugikan peminjam.

Istilah riba dibagi menjadi dua, yaitu: riba an-nasi'ah dan riba al-fadl. Istilah nasi'ah berasal dari akar kata nasa'a yang berarti menunda, menangguhkan atau menunggu dan merujuk pada waktu yang diberikan kepada peminjam dengan imbalan berupa premi. Riba ini dikatakan sama dengan bunga yang dikenakan kepada peminjam, sedangkan dikatakan riba al fadl apabila salah satu dari kedua pihak yang bertransaksi menerima suatu kelebihan. Contohnya adalah menukarkan barang sejenis yang tidak sama kualitas dan sengaja 
melakukan kesalahan dalam menimbang barang yang diperjual belikan.

Kerugian yang disebabkan oleh riba membuat riba tidak hanya dilarang dalam ajaran Islam, tetapi juga dilarang dalam ajaran agama lain. Misalkan dalam ajaran Yahudi dijelaskan pada Eksodus 22:25, Deutronomy 23:19, Levicitus 35:7 dan Lukas 6:34:35 dan ajaran Kristen yang dijelaskan pada pandang reformis Kristen pada abad XVI-1836 (Mardiyah, 2012). Alternatif yang ditawarkan Islam sebagai pengganti bunga atau riba adalah menerapkan bagi hasil dimana kedua belah pihak berbagi resiko dan keuntungan sesuai kesepakatan yang dibuat di awal transaksi. Hal ini dilakukan agar tidak ada pihak yang terdzalimi oleh pihak lain.

\section{A suransi dalam Islam}

Kata asuransi pada umumnya berasal dari dari Bahasa Inggris, yaitu insurance, yang dalam bahasa Indonesia mempunyai arti kata "pertanggungan". Secara umum pengertian asuransi adalah salah satu cara atau metode untuk memelihara manusia dalam menghindari resiko atau ancaman bahaya yang beragam yang akan terjadi dalam hidupnya (Sula, 2004).

Tujuan asuransi dalam Islam yang menjadi kebutuhan mendasar adalah alKidayah berarti kecukupan dan al-Amnu berarti keamanan, oleh karena itu Islam menyuruh kepada umatnya untuk mencari rasa aman baik untuk diri sendiri maupun keluarga di masa mendatang. Hal ini tersirat dalam QS. AI-Maidah: 2 yang berarti: “...dan tolong-menolonglah kamu dalam (mengerjakan) kebajikan dan takwa, dan jangan tolong-menolong dalam berbuat dosa dan pelanggaran. Dan bertakwalah kamu kepada Allah, sesungguhnya Allah amat berat siksa-Nya".

Ayat ini memuat perintah untuk saling tolong-menolong dan bekerja sama antar manusia karena sebagai mahluk yang lemah, manusia harus senantiasa sadar bahwa keberadaanya tidak akan mampu hidup sendiri tanpa bantuan orang lain atau sesamanya.

Jenis akad yang biasa digunakan dalam asuransi yaitu akad mudharabah dan wakalah bil ujrah. Mudharabah adalah suatu akad antara pemilik harta yang memberikan kepada mudharib, orang yang bekerja atau pengusaha, suatu harta supaya dia mengelolah dalam bisnis dan keuntungan dibagi antara kedua belah pihak. Penerapan akad mudharabah dalam bisnis asuransi syari'ah terwujud tatkala dana terkumpul dalam perusahaan asuransi diinvestasikan dalam wujud usaha yang diproyeksikan menghasilkan keuntungan di masa depan. Karena dalam akad mudharabah ini terdapat prinsip profit-loss sharing, maka jika dalam investasinya mendapatkan keuntungan maka keuntungan tersebut dibagi bersama sesuai akad yang disepakati.

Sebaliknya jika dalam investasinya mengalami kerugian maka kerugian tersebut dipikul bersama antara peserta asuransi dan perusahaan. Sedangkan akad wakalah bil ujrah dalam asuransi syari'ah adalah suatu akad wakalah (pemberian kuasa) dari peserta kepada perusahaan asuransi untuk mengelolah dana peserta dengan memperoleh imbalan (ujrah/ fee). Dana peserta ini disebut dana tabarru'. Pengelolahan dana tabarru' dilakukan oleh perusahaan asuransi dengan akad yang telah disepekati sebelumnya. Dalam dunia matematika aktuaria, konsep dana tabarru' ini sama dengan konsep premi dalam bidang asuransi.

\section{Konsep Premi (Pr) dalam Asuransi}

Matematika aktuaria adalah salah satu disiplin ilmu yang menggabungkan matematika, statistika dan ekonomi yang berperan dalam menilai atau memperkirakan resiko terutama pada bidang asuransi dan keuangan perusahaan. Dalam ilmu ini dikenal istilah premi (Pr) yang merupakan sejumlah uang yang harus dibayarkan pada setiap periode waktu sebagai kewajiban dari tertanggung atas keikutsertaannya di asuransi. Besar premi yang harus dibayarkan 
ditentukan oleh perusahaan asuransi dengan memperhatikan keadaan-keadaan dari tertanggung. Menurut (Gerber, 1997) terdapat tiga bentuk pembayaran premi, antara lain: (1) Premi tunggal (one single premium), (2) Premi berkala dengan jumlah tetap (level premium), (3) Premi berkala dengan jumlah bervariasi

Misalkan $L$ adalah total kerugian atau loss yang merupakan selisih antara benefit dan pembayaran premi maka suatu premi dikatakan premi bersih jika memenuhi equivalence principle yaitu nilai ekspektasi dari kerugian bernilai 0 . Equivalence principle memenuhi persamaan sebagai berikut: $E[L]=0$

$E[$ premi $]-E[$ benefit $]=0$

$E[$ premi $]=E[$ benefit $]$

\section{Algoritma G enetika}

Algoritma genetika merupakan salah satu teknik pencarian heuristic yang didasarkan pada gagasan evolusi seleksi alam dan genetika (Suyanto, 2005). Algoritma ini ditemukan oleh John Holland pada tahun 1975 di Universitas Michigan melalui sebuah penelitian dan dipopulerkan oleh salah satu muridnya, David Goldberg. Konsep dasar algoritma genetika sebenarnya dirancang untuk menyimpulkan proses-proses dalam system alam yang diperlukan untuk proses evolusi, khususnya teori evolusi alam yang dicetuskan oleh Charles Darwin, yaitu survival of fittest. Menurut teori ini, di alam terjadi persaingan antara individu-individu untuk memperebutkan sumber daya alam yang langka sehingga individu yang kuat akan mendominasi individu yang lemah.

Berikut komponen utama dalam algoritma genetika. (1) Teknik encoding atau decoding gen dari individu. Encoding berguna untuk membuat kode dari nilai gen pembentuk individu dan decoding berguna untuk membuat kode dari gen pembentukan individu agar nilainya tidak melebihi range yang telah ditentukan dan sekaligus menjadi nilai variabel yang akan dicari solusi permasalahannya; (2) Pembangkitan populasi awal secara acak; (3) Penentuan nilai fitness yang merupakan nilai dari fungsi tujuan dimana tujuan dari algoritma genetika adalah memaksimalkan nilai fitness. Nilai fitness inilah yang digunakan sebagai ukuran baik tidaknya suatu solusi; (4) Elitisme adalah prosedur untuk mengcopy individu bernilai fitness sebanyak satu (jika jumlah individu dalam populasi adalah ganjil) atau dua (jika jumlah individu dalam suatu populasi adalah genap). Hal ini dilakukan agar individu tersebut tidak memiliki kerusakan, nilai fitness menurun selama proses pindah silang dan mutasi; (5) Seleksi digunakan untuk memilih dua buah individu yang akan dijadikan sebagai orang tua; (6) Pindah silang adalah tahapan yang melibatkan dua induk untuk menghasilkan keturunan yang baru; (7) Mutasi berperan untuk menggantikan gen yang hilang dari populasi akibat proses seleksi; (8) Penggantian populasi dimaksudkan bahwa semua individu awal dari satu generasi diganti dengan individu baru hasil proses pindah silang dan mutasi.

Dalam jurnal ini, algoritma genetika digunakan untuk menentukan nilai premi optimal pada model profit-loss sharing dengan penambahan dana tabarru'.

\section{METODE PENELITIAN Pembangkitan Laba Bersih H arian Peda- gang}

Konsep dari tahapan ini menggunakan prinsip Probability Integral Transform (PIT) dimana suatu data dapat dibangkitkan dengan menggunakan distribusi kumulatifnya. Oleh karena itu berdasarkan (Sumarti et al. 2014, 2015), data laba bersih yang didapat dari pemberian kredit mikro sejumlah Rp. 1.000.000 kepada 5 pedagang disalah satu pasar di Bandung ditentukan distribusinya sesuai kondisi yang diinginkan. Penentuan ditribusi untuk setiap laba bersih pedagang dilakukan dengan menggunakan software easyfit. Software ini merupakan salah satu software aplikasi simuIasi dan analisis data yang dapat memberikan gambaran distribusi sesuai dengan data yang diberikan (Mathwave, 2015). 
Hasil yang didapat dari easyfit terdiri atas 3 bagian untuk setiap data, yaitu: graphs, summary dan goodness of fit. Graphs memberikan grafik data sesuai dengan distribusi yang memenuhi. Summary memberikan distribusi beserta parameter yang sesuai dengan data, sedangkan goodness of fit memberikan hasil pengujian berupa hasil numerik dan peringkat berdasarkan uji Kolmogorov Smirnov, Anderson Darling dan Chi-Squares. Peringkat pada bagian inilah yang digunakan untuk memilih distribusi yang paling cocok dengan data asli.

Setelah menetapkan distribusi setiap data, dilakukan pembangkitan data menggunakan Matlab R 2009i. Pembangkitan disesuaikan dengan lama periode yang diperlukan. Misalkan, jika distribusi dan parameter didapat untuk data dengan lama periode 52 hari maka pembangkitan juga dilakukan untuk 52 hari. Selanjutnya dilakukan pencocokan menggunakan data asli. Jika data bangkitan memiliki ukuran data untung dan rugi sama maka distribusi tersebut digunakan sebagai dasar pembangkitan data lebih lanjut.

\section{Model PLS dengan Penambahan Dana Tabarru'}

Model investasi ini merupakan pengembangan dari model investasi syari'ah pada (Sumarti et al. 2014). Berbeda dengan model sebelumnya, dalam artikel ini ditambahkan dana tabarru' $(Q(t))$ dalam proses pelunasan. Tujuan penambahan ini adalah untuk membantu pedagang dalam pelunasan iuran pokok yaitu sebesar $I p=\frac{A}{T}$ pada hari ke-t. Hal ini membuat pedagang tidak memiliki hutang maupun cicilan seperti model PLS sebelumnya. A turan yang berlaku pada model ini, antara lain: (1) Model menetapkan $Q(t)$ sebagai perwujudan profit-loss sharing dengan pem bayarannya dilakukan setelah angsuran pokok $I(t)$ dan bagi hasil $B(t)$ dipenuhi, (2) Benefit atau santunan diberikan kepada pedagang jika $w(t)<$ Ip dengan kata lain pedagang tidak mampu melunasi angsuran pokok pada hari ke $t$.

Persamaan dana tabarru' $Q(t)$ pada hari ke $t$ diberikan sebagai berikut:

$$
Q(t)=\left\{\begin{array}{cc}
\overline{P r} & , w(t)-I(t)-\overline{P r}>0 \\
0 & , w(t)-I(t)-\overline{P r} \leq 0
\end{array}\right.
$$

Dengan $I(t)$ merupakan angsuran pada hari ke- $t$. Besar $I(t)$ ditentukan berdasarkan besarnya $w(t)$. Jika $w(t)$ pada hari ke- $t$ lebih besar daripada Ip maka $I(t)=I p$ dan jika $0<w(t)<I p$ maka $I(t)=w(t)$, sedangkan jika pedagang tidak dapat melunasi I $p$ pada hari ke- $t$ maka pedagang akan mendapatkan $b(t)$ sebesar kekurangan I $p$ pada hari yang sama.

Total angsuran $S(t)$ pada model ini pada hari ke $t$ memenuhi persamaan:

$S(t)=I(t)+B(t)+b(t)$

$B(t)$ merupakan besarnya bagi hasil pada hari ke $t$ yang bergantung pada porsi bagi hasil $p$ yang harus ditentukan terlebih dahulu. Penentuan nilai $p$ yang optimal akan dibahas pada uraian selanjutnya. Persamaan $B(t)$ diberikan sebagai berikut:

$B(t)=\left\{\begin{array}{c}p \times(w(t)-I(t)), w(t)-I(t)>0 \\ 0, w(t)-I(t) \leq 0\end{array}\right.$

$B(t)$ dibayarkan ketika laba bersih pe dagang lebih besar daripada angsuran pada hari yang sama $(w(t)-I(t)>0)$ dan

jika kondisi tersebut tidak dipenuhi maka pedagang tidak harus membayar $B(t)$.

Tabel 1 merupakan ilustrasi yang untuk model $P L S$ dengan penambahan $Q(t)$ de ngan $A=1.000 .000$ merupakan total investasi dengan porsi bagi hasil yang dipilih $p=$ 0,5, maka untuk $T=20$ hari dan $\overline{P r}=$ 15.000. Implementasi model pada ilustrasi dilakukan untuk setiap hari ke-t. $T H(t)$ merupakan banyaknya uang atau laba bersih yang dibawa pulang oleh pedagang pada hari ke-t. Perhitungan $T H(t)$ diperlukan pada analisis model $P L S$ selanjutnya.

Analisis model dilakukan dengan perhitungan porped $d_{\text {syar }+ \text { tab }}$ dan $r_{\text {syar }+ \text { tab }}$ yang menunjukkan profit bagi kedua belah pihak terkait. Profit bagi pedagang pada model 
investasi ini disebut proped $d_{\text {syar+tab }}$ yang didapat dari pehitungan persamaan sebagai berikut:

porped $_{\text {syar }+ \text { tab }}=\frac{\sum_{i=1}^{T} F V(T H)}{\sum_{i=1}^{T} F V(w)}$

dengan

$$
T H(t)=w(t)-S(t)-Q(t)
$$

Asumsi yang digunakan dalam perhitungan ini adalah laba bersih yang didapat diletakkan di bank dengan menggunakan $r_{B I}=7,5 \%$ yang merupakan rate $\mathrm{BI}$, sedangkan untuk $r_{\text {syar }+ \text { tab }}$ merupakan profit yang didapat oleh investor. Profit ini memenuhi persamaan sebagai berikut:

$A=\frac{S(1)}{\left(1+r_{\text {syar }+t a b}\right)}+\cdots+\frac{S(T)}{\left(1+r_{\text {syar }+t a b}\right)^{T}}$

Penyelesaian persamaan $r_{\text {syar }+t a b}$ dilakukan dengan simulasi metode numerik bagi dua menggunakan Matlab $R$ 2009i. Berbeda dengan model sebelumnya, pada model ini tidak ditambahkan hutang terakhir karena hutang pedagang selalu terlunasi dengan penambahan $Q(t)$.

\section{Penentuan Porsi Bagi Hasil Optimal}

Porsi bagi hasil merupakan salah satu komponen penting dalam model bagi hasil syari'ah. Penentuan porsi bagi hasil yang salah akan membuat model bagi hasil tidak mencapai tujuan memberikan keadilan bagi investor dan pedagang. Berikut ini merupakan langkah-langkah yang dilakukan untuk menentukan porsi bagi hasil optimal:

1. Membangkitkan data laba bersih pedagang untuk periode investasi $T$.

2. Tentukan porped $_{\text {rent }}$ dan $r_{\text {rent }}$ menggunakan model angsuran rentenir.

3. Bangkitkan 500 nilai porsi bagi hasi pada selang $[0,001,0,5]$ dengan sub selang 0,001 .

4. Untuk setiap porsi bagi hasil ditentukan porped $_{\text {syar dan }} r_{\text {syar }}$ dengan menggunakan model profit-loss sharing.

5. Tentukan selang porsi nagi hasil yang memenuhi:

$$
\begin{gathered}
r_{B I}<r_{\text {syar }}<r_{\text {rent }} \\
\text { porped }_{\text {syar }}<\text { porped }_{\text {rent }}
\end{gathered}
$$

Tabel 1

Ilustrasi model investasi syari'ah dengan penambahan dana tabarru'

\begin{tabular}{cccccccc}
\hline \hline $\boldsymbol{t}$ & $\boldsymbol{w}(\boldsymbol{t})$ & $\boldsymbol{I}(\boldsymbol{t})$ & $\boldsymbol{B}(\boldsymbol{t})$ & $\boldsymbol{Q}(\boldsymbol{t})$ & $\boldsymbol{b}(\boldsymbol{t})$ & $\boldsymbol{S}(\boldsymbol{t})$ & $\boldsymbol{T H}(\boldsymbol{t})$ \\
\hline 1 & 70000 & 50000 & 10000 & 0 & 0 & 60000 & 10000 \\
2 & -10000 & 0 & 0 & 0 & 50000 & 50000 & -60000 \\
3 & 30000 & 30000 & 0 & 0 & 20000 & 50000 & -20000 \\
4 & 150000 & 50000 & 50000 & 15000 & 0 & 100000 & 35000 \\
$\vdots$ & $\vdots$ & $\vdots$ & $\vdots$ & $\vdots$ & $\vdots$ & $\vdots$ & $\vdots$ \\
\hline 20 & & & & & & &
\end{tabular}

Sumber: Hasil I mplementasi M odel

6. Selang porsi bagi hasil yang didapat pada tahap sebelumnya digunakan untuk menentukan porsi bagi hasil opti mal menggunakan model keoptimalan. Terdapat beberapa model keoptimalan yang digunakan dalam artikel ini. Hal ini bertujuan untuk mendapatkan simpulan tentang model keoptimalan yang optimal beserta sifat setiap model. Model ini dibangun berdasarkan model keoptimalan pada (Mustika, 2013). Berikut model keoptimalan porsi bagi hasil yang digunakan:

Model Keoptimalan 1

$\max F(p)=\alpha\left(\frac{f(p)}{f_{\max }}\right)^{2}+(1-\alpha)\left(\frac{g(p)}{g_{\max }}\right)^{2}$

$f(p)=r_{\text {syar }+ \text { tab }}(p)-r_{B I}$

$g(p)=$ porped $_{\text {syar }+ \text { tab }}(p)-$ porped $_{\text {rent }}$

$f_{\text {max }}=\max |f(p)|$

$g_{\max }=\max |g(p)|$

$\alpha=0.1, \ldots, 1$ merupakan bobot yang me

nyatakan keterpihakan 
Model Keoptimalan 2

$$
\begin{aligned}
& \max F(p)=\alpha\left(\frac{f(p)}{f_{\max }}\right)^{2}+(1-\alpha)\left(\frac{g(p)}{g_{\max }}\right)^{2} \\
& f(p)=r_{\text {syar }+ \text { tab }}(p)-r_{B I} \\
& g(p)=\text { porped }_{\text {syarttab }}(p)-2 \text { porped }_{\text {rent }} \\
& f_{\max }=\max |f(p)| \\
& g_{\max }=\max g(p) \mid \\
& \alpha=0.1, \ldots, 1 \text { merupakan bobot yang me } \\
& \text { nyatakan keterpihakan }
\end{aligned}
$$

Model keoptimalan 1 pada persamaan [7] dan 2 pada persamaan [8] menggunakan fungsi objektif yang merupakan penjumlahan antara kuadrat $r_{\text {syar }}$ dan $r_{B I}$ dibagi maksimum dari semua selisih dengan bobot $\alpha$ dan hasil kuadrat selisih porped $_{\text {syar }}$ dan porped $_{\text {rent }}$ dibagi maksimum dari semua selisih dengan bobot $1-\alpha$. Nilai $f(p)$ menyatakan pay off yang akan diterima investor dengan penggunaan model profit-loss sharing. Dengan kata lain, pada $f(p)$ diharapkan bahwa $r_{\text {syar }}$ jaraknya sejauh mungkin dengan $r_{B I}$ yang artinya menghasilkan profit yang besar untuk investor, sedangkan $g(p)$ menyatakan payoff yang akan diterima pedagang apabila menggunakan model ini. Pada model keoptimalan 2 didapat bahwa $g(p)$ akan menghasilkan nilai yang negative namun dengan pengkuadratan pada fungsi objektif maka akan menghasilkan nilai positif yang besar. $\mathrm{Hal}$ ini bertujuan agar didapat profit pedagang yang besar juga.

Memaksimalkan $F(p)$ merupakan memaksimalkan jarak antara $r_{\text {syar }}$ dengan $r_{B I}$ dan porped syar dengan porped $_{\text {rent }}$ dengan $\alpha$ merupakan suatu porsi keterpihakan. Semakin besar $\alpha$ maka semakin besar keterpihakannya kepada investor dan sebaliknya se makin $\alpha$ semakin besar keterpihakan kepada pedagang.

Model Keoptimalan 3

$$
\begin{aligned}
\min F(p) & =\alpha\left(\frac{f(p)}{f_{\max }}\right)^{2}+(1-\alpha)\left(\frac{g(p)}{g_{\max }}\right)^{2} \\
f(p) & =r_{\text {syar }+ \text { tab }}(p)-k \cdot r_{B I}
\end{aligned}
$$

$$
\begin{aligned}
& g(p)=\operatorname{porped}_{\text {syartab }}(p)-\text { porped }_{\text {rent }} \\
& f_{\text {max }}=\max f(p) \mid \\
& g_{\max }=\max |g(p)| \\
& \alpha=0.1, \ldots, 1 \text { merupakan bobot yang } \\
& \text { menyatakan keterpihakan }
\end{aligned}
$$

Model Keoptimalan 4

$$
\begin{aligned}
\min F(p) & =\alpha\left(\frac{f(p)}{f_{\max }}\right)^{2}+(1-\alpha)\left(\frac{g(p)}{g_{\max }}\right)^{2} \quad \text { [10] } \\
f(p) & =r_{\text {syar }+ \text { tab }}(p)-k \cdot r_{B I} \\
g(p) & =\text { porped }_{\text {syarttab }}(p)-2 \text { porped }_{\text {rent }} \\
f_{\max } & =\max |f(p)| \\
g_{\max } & =\max g(p) \mid \\
\alpha & =0.1, \ldots, 1 \text { merupakan bobot yang }
\end{aligned}
$$$$
\text { menyatakan keterpihakan }
$$$$
k=\text { pengali } r_{B I}
$$$$
\text { Model keoptimalan } 3 \text { pada per- }
$$
samaan [9] dan 4 pada persamaan [10] menggunakan fungsi objektif yang merupakan penjumlahan antara kuadrat selisih $r_{\text {syar }}$ dan kelipatan $r_{B I}$ dibagi maksimum dari semua selisih dengan bobot $\alpha$ dan hasil kuadrat selisih porped $_{\text {syar }}$ dan porped rent $_{\text {re }}$ dibagi maksimum dari semua selisih dengan bobot $1-\alpha$. Pada $f(p)$ diharapkan bahwa $r_{\text {syar }}$ jaraknya sedekat mungkin dengan $r_{B I}$ sedangkan $g(p)$ pada model keoptimalan 4 dibuat sama dengan model keoptimalan 2.

Meminimumkan $F(p)$ merupakan meminimumkan jarak antara $r_{\text {syar }}$ dengan kelipatan $r_{B I}$ dan porped syar $_{\text {san }}$ dengan porped $_{\text {rent }}$. Pembagian fungsi objektif pada semua model keoptimalan dengan $f_{\text {maks }}$ dan $g_{\text {maks }}$ dilakukan agar $F(p)$ tidak memiliki dimensi dan agar bernilai maksimal 1 .

7. Porsi bagi hasil optimal digunakan untuk proses implementasi selanjutnya.

\section{Penentuan Premi Optimal}

Dalam jurnal ini, konsep premi berkala dengan jumlah tetap digunakan sebagai dasar pembayaran Pr untuk setiap periode waktu. Berdasarkan persamaan equival nn rn principle didefinisikan persamaan sisa c [9] tabarru' (SDT) sebagai berikut: 
$S D T=\sum_{i=0}^{T} a_{i} \overline{P r}\left(1+r_{B I}\right)^{T-i}-\sum_{i=0}^{T} b_{i}\left(1+r_{B I}\right)^{T-i}$

dengan,

$\overline{P r}=$ premi rata-rata

$a_{i}=$ pengali premi $= \begin{cases}1 & , w(t) \geq I p \\ 0 & , w(t)<0\end{cases}$

$b(t)=\left\{\begin{array}{cl}I p & , w(t) \geq I p \\ I p-w(t) & , 0<w(t)<I p \\ 0 & , w(t) \leq 0\end{array}\right.$

$w(t)=$ laba bersih pada hari ke $t$

$r_{B I}=\frac{7.5 \%}{252}$ adalah $\mathrm{BI}$ rate harian

$T=$ lama periode investasi

Sesuai dengan konsep premi bersih maka diharapkan $S D T \approx 0$, namun dalam prakteknya, tidak selalu didapatkan $S D T \approx$ 0 . Dalam menyelesaikan masalah optimasi ini digunakan algoritma genetika untuk mendapatkan $a_{i}$ yang optimal.

Tujuan awal penggunakan algoritma genetika dalam artikel ini adalah mendapatkan $S D T \approx 0$ sehingga fungsi objektif yang digunakan untuk permasalahan ini adalah:

$\min _{a} F(a)=S D T+(\mu \times H(a) \times|S D T|)$

dengan,

$\mu=10^{7}$ yang merupakan penalti/ denda

$H(a)= \begin{cases}1 & , S D T<0 \\ 0 & , S D T \geq 0\end{cases}$

Cara kerja fungsi objektif ini adalah mencari minimum dari $F(a)$ dengan $a$ merupakan output yang diharapkan. Kendala dalam fungsi objektif ini bertujuan jika $S D T<0$ maka didapat $H(a)=1$. Hal ini membuat fungsi objektif bernilai sangat besar karena menambahan penalty, sehingga tidak akan menjadi pilihan solusi. Sedangkan jika $S D T \geq 0$ maka $H(a)=0$ sehingga fungsi objektif bernilai $S D T$. Selanjutnya $S D T>0$ dan minimum yang akan terpilih menjadi solusi optimal.

\section{ANALISIS DAN PEMBAHASAN Pembangkitan D ata}

Data yang digunakan merupakan data dari lima pedagang disalah satu pasar di Bandung. Data ini diperoleh dari pencatat- an harian pedagang setelah menerima modal tambahan sebesar Rp. 1.000.000. Berdasarkan lama periode yang telah ditentukan, yaitu $T=30, T=52$ dan $T=90$ hari, maka ditentukan distribusi untuk setiap data pedagang dan lama periode investasinya.

Tabel 3 merupakan hasil dari penentuan distribusi dan parameter menggunakan easyfit. Pembangkitan dilakukan secara acak menggunakan MatlabR2099i sesuai dengan lama periode investasi. Data bangkitan inilah yang selanjutnya akan digunakandalam tahapan berikutnya, sedangkan Gam bar 1, 2 dan 3 merupakan histogram untuk setiap distribusi data pedagang. Histogram merupakan tampilan grafis dari tabulasi frekuensi yang digambarkan dengan grafis batangan sebagai manifestasi data binning.

\section{Simulasi dan Implementasi Model}

Langkah awal yang dilakukan adalah mencari rata-rata dari data laba bersi h untuk setiap pedagang. Hal ini dilakukan karena investasi hanya diberikan kepada pedagang dengan rata-rata laba bersih lebih besar dari $\mathrm{O}(w(t)>0)$. Berdasarkan Tabel 2 didapat bahwa pedagang 3 dan 5 tidak dapat diterapkan untuk model investasi ini dikarenakan nilai negative pada rata-rata laba bersihnya yang menunjukkan bahwa pedagang selalu mengalami kerugian untuk semua lama periode, sehingga pedagang 1, 2 dan 4 akan digunakan untuk simulasi selanjutnya.

Tabel 2

Rata-rata laba bersih setiap pedagang dengan $A=R p .1 .000 .000$

\begin{tabular}{cccc}
\hline \hline Ped & $\overline{\boldsymbol{w}}_{\boldsymbol{T}=\mathbf{3 0}}$ & $\overline{\boldsymbol{w}}_{\boldsymbol{T}=\mathbf{5 2}}$ & $\overline{\boldsymbol{w}}_{\boldsymbol{T}=\mathbf{9 0}}$ \\
\hline 1 & 333436.43 & 363113.46 & 254989.27 \\
2 & 57827.28 & 59655.02 & 67353.48 \\
3 & -112015.57 & -115485.37 & -89639.30 \\
4 & 54102.64 & 54950.46 & 45271.08 \\
5 & -70258.19 & -77918.71 &
\end{tabular}

Sumber: Hasil Simulasi Rata-rata Laba Bersih

Data bangkitan untuk pedagang 1, 2 dan 4 diperoleh berdasarkan proses pembangkitan pada uraian sebelumnya. Setiap 
data bangkitan diimplementasi pada model investasi. Proses ini diperlukan tahapan penentuan porsi bagi hasil optimal untuk model syari'ah. Sesuai kriteria keoptimalan model syari'ah, diperlukan implementasi data pada model angsuran rentenir.
Model rentenir yang digunakan me rupakan hasil penelitian dari (Fitriani, 2014). Dalam model ini dijelaskan bahwa model menetapkan 30\% sebagai bunga, $10 \%$ sebagai biaya administrasi dan menetapkan denda untuk setiap keterlambatan.

\section{Tabel 3}

Distribusi data dengan lama periode berbeda dengan $A=R p \cdot 1.000 .000$

\begin{tabular}{|c|c|c|}
\hline Pedagang & D istribusi & Parameter \\
\hline & & $T=30$ \\
\hline 1 & Weibull 3P & $\alpha=2.2836 ; \beta=1.75 e+6 ; \gamma=-1.21 e+6$ \\
\hline 2 & Gamma & $\alpha=4.495 ; \beta=12710$ \\
\hline 3 & Weibull 3P & $\alpha=2.441 e+8 ; \beta=4.8278 e+13 ; \gamma=-4.8278 e+13$ \\
\hline 4 & Weibull & $\alpha=3.023 ; \beta=60201$ \\
\hline 5 & Weibull 3P & $\begin{array}{c}\alpha=3.5552 e+8 ; \beta=4.6172 e+13 ; \gamma=-4.6172 e+13 \\
\quad T=52\end{array}$ \\
\hline 1 & Weibull 3P & $\alpha=2.2943 ; \beta=1.72 e+6 ; \gamma=-1.20 e+6$ \\
\hline 2 & Gamma & $\alpha=3.2459 ; \beta=18396$ \\
\hline 3 & Weibull 3P & $\alpha=4.66 e+8 ; \beta=9.32 e+13 ; \gamma=-9.32 e+13$ \\
\hline 4 & Weibull 3P & $\alpha=2.642 ; \beta=50132 ; \gamma=13370$ \\
\hline 5 & Weibull 3P & $\begin{array}{c}\alpha=76597 ; \beta=1.0676 e+10 ; \gamma=-1.0676 e+10 \\
\quad T=90\end{array}$ \\
\hline 1 & Weibull 3P & $\alpha=2.8877 ; \beta=2.09 e+6 ; \gamma=-1.61 e+6$ \\
\hline 2 & Gamma & $\alpha=1.4779 ; \beta=44772$ \\
\hline 3 & Weibull 3P & $\alpha=2.4878 e+8 ; \beta=3.786 e+13 ; \gamma=-3.786 e+13$ \\
\hline 4 & Weibull 3P & $\alpha=3.2316 ; \beta=80154 ; \gamma=-26500$ \\
\hline
\end{tabular}

Sumber: H asil Simulasi Software Easyfit

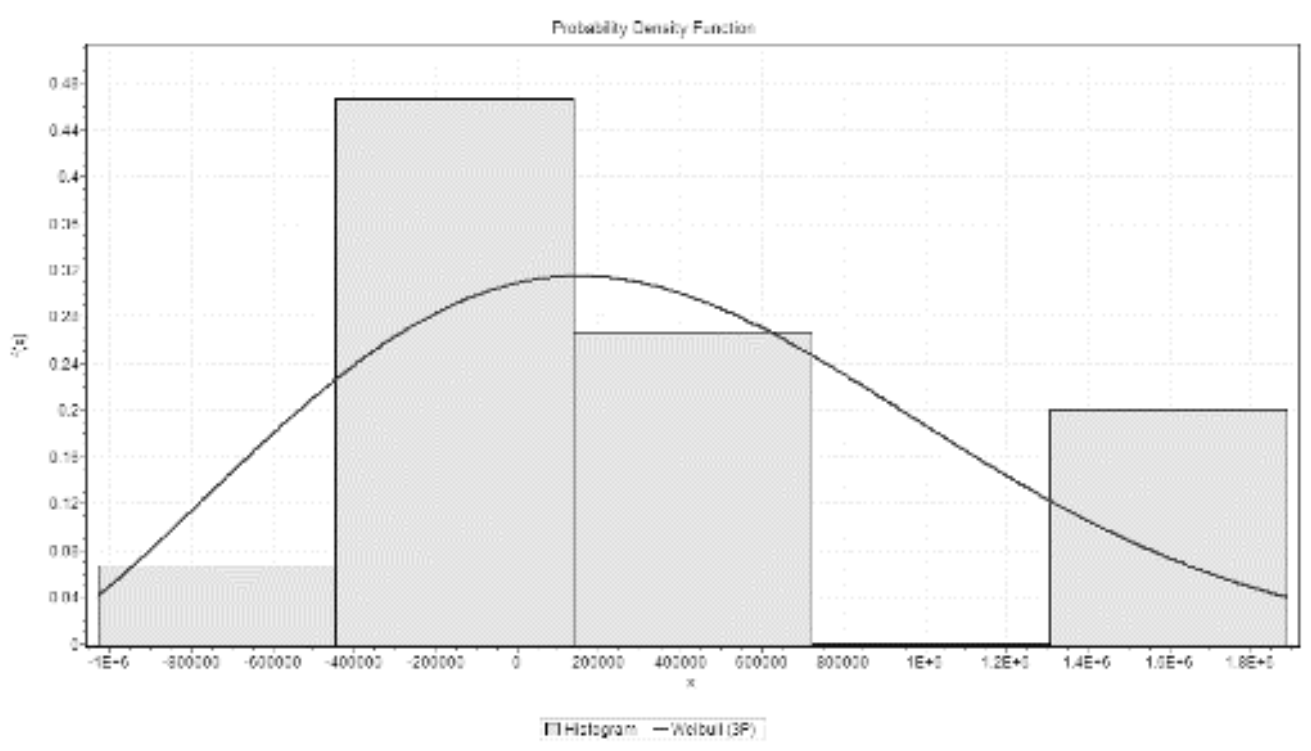

(a) 
132 Ekuitas: Jurnal Ekonomi dan Keuangan - V olume 1, N omor 1, M aret 2017 : 122 - 143

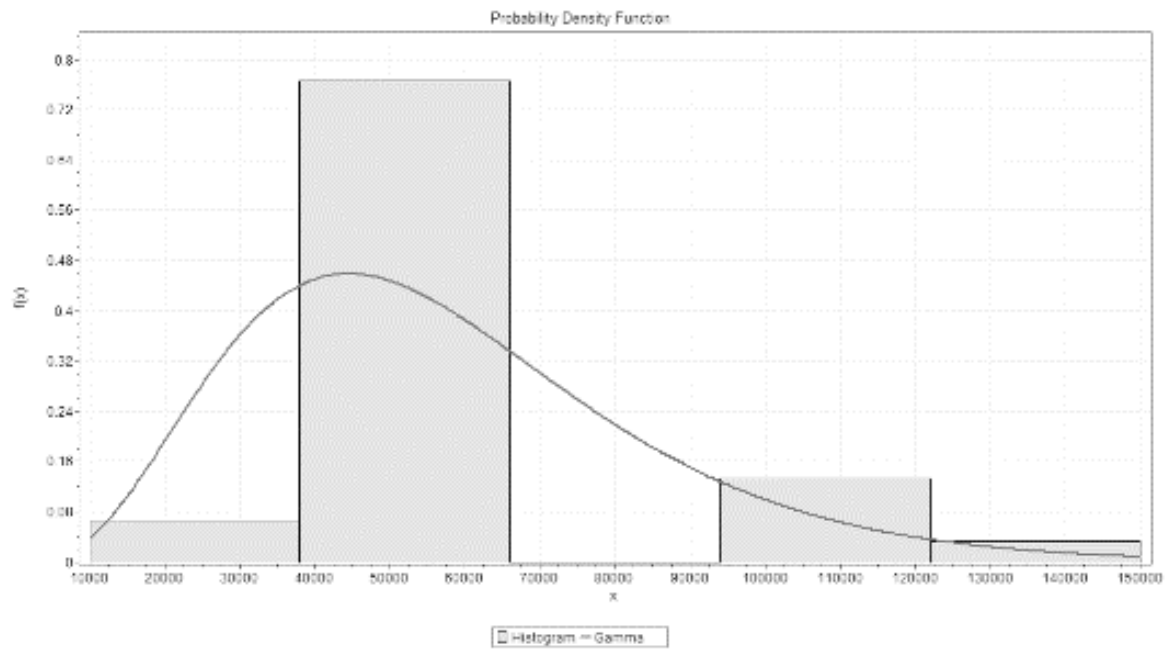

(b)

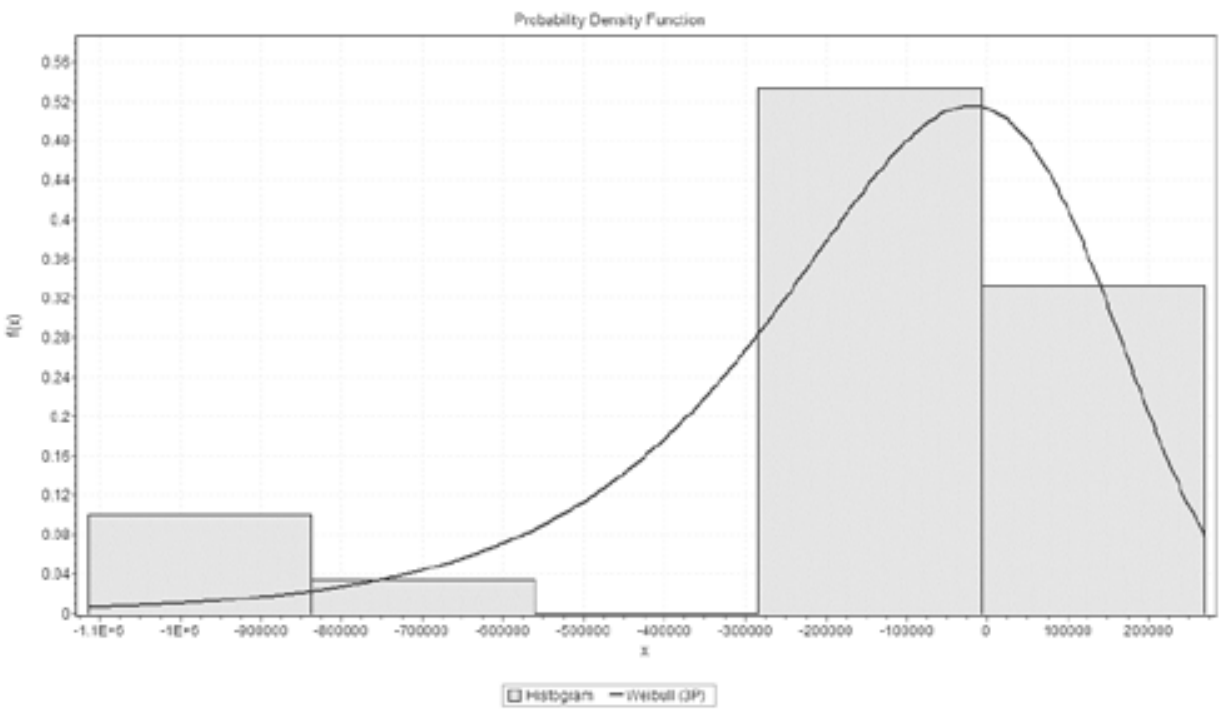

(c)

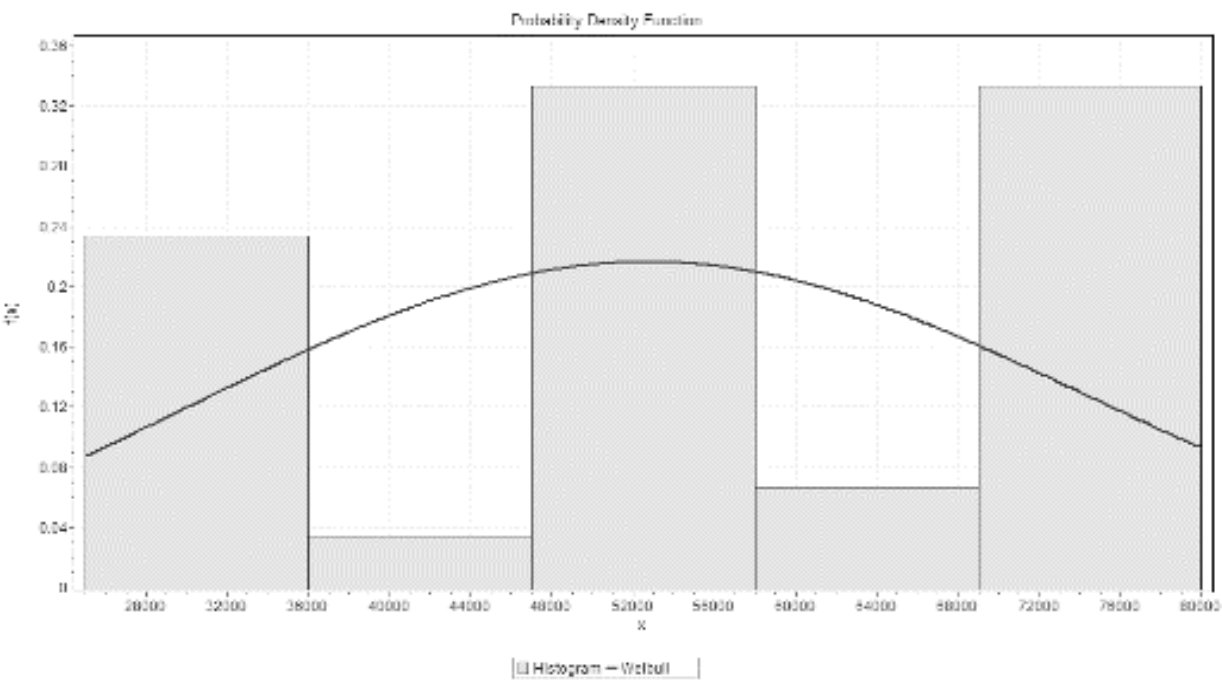

(d) 


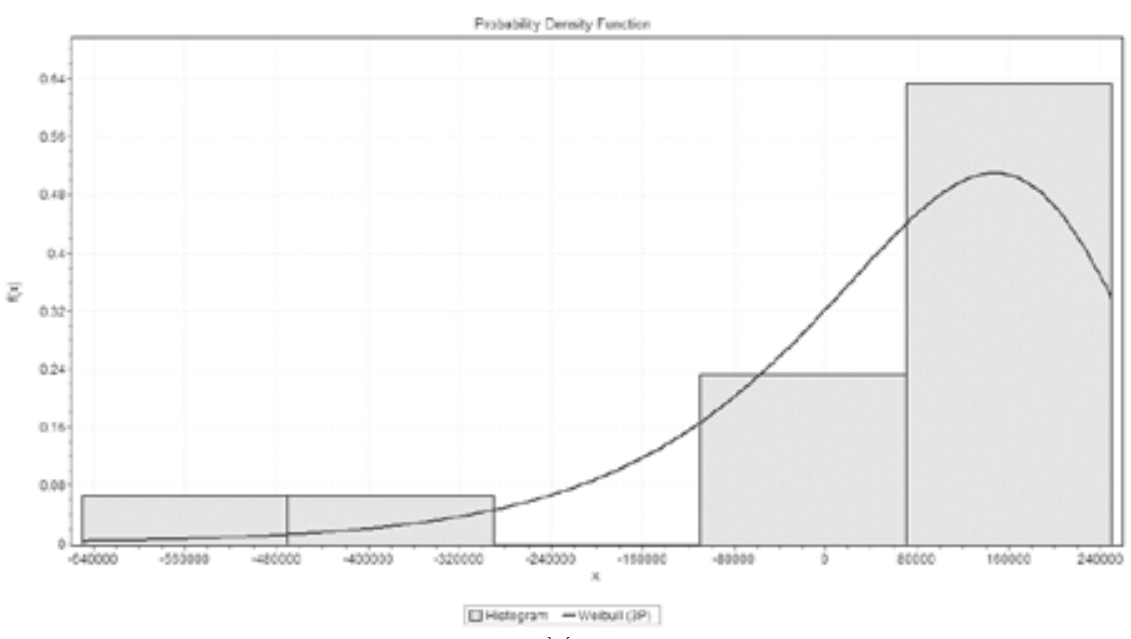

(e)

Sumber: H istogram Hasil Simulasi Software Easyfit

G ambar 1

H istogram untuk $T=30$ dengan $A=R p .1 .000 .000$

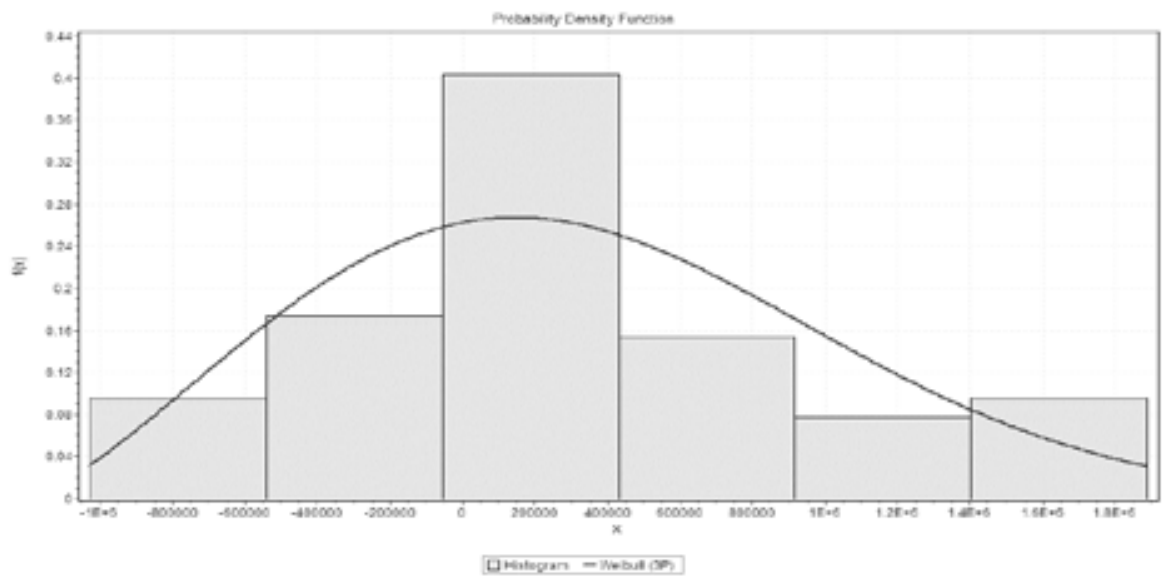

(a)

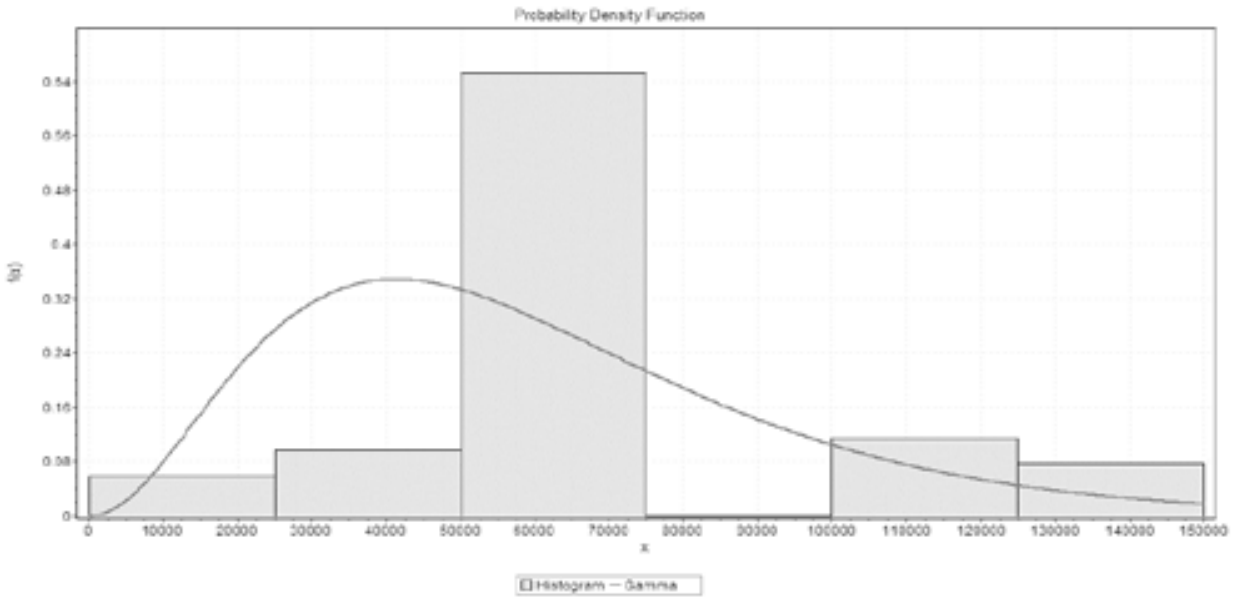

(b) 
134 Ekuitas: Jurnal Ekonomi dan Keuangan - V olume 1, N omor 1, M aret 2017 : 122 - 143

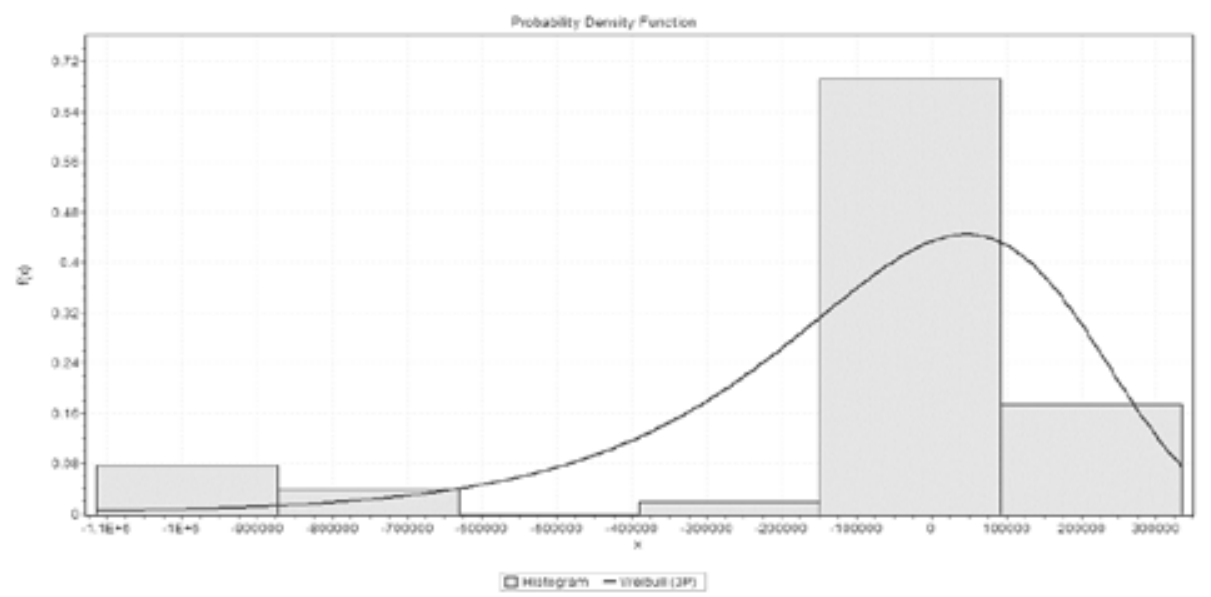

(c)

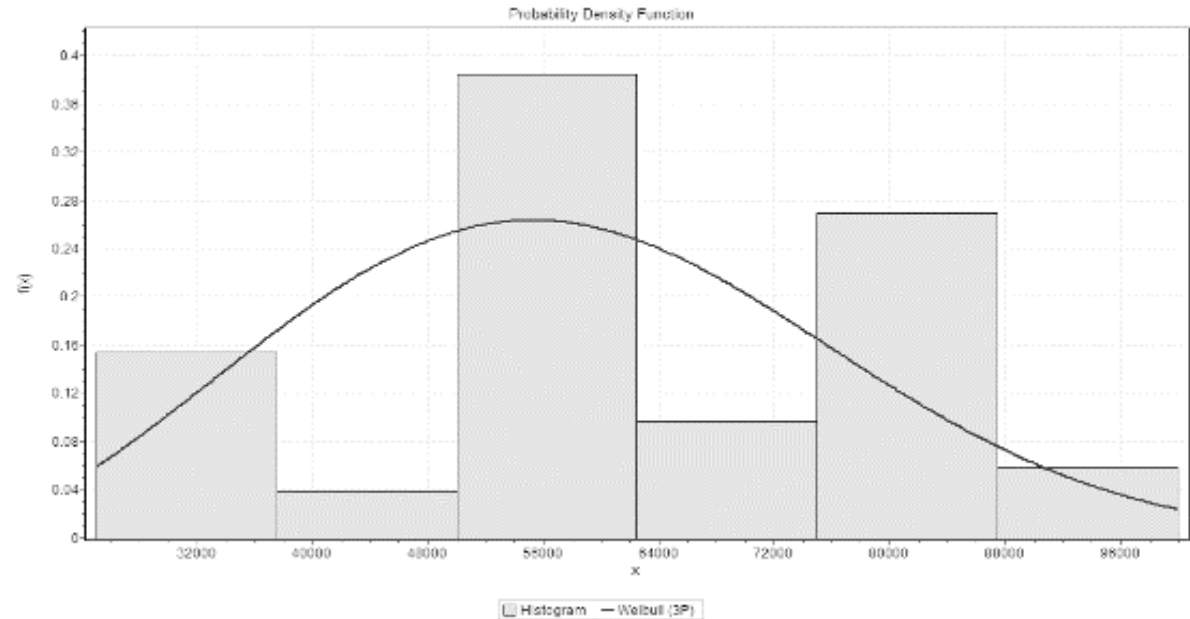

(d)

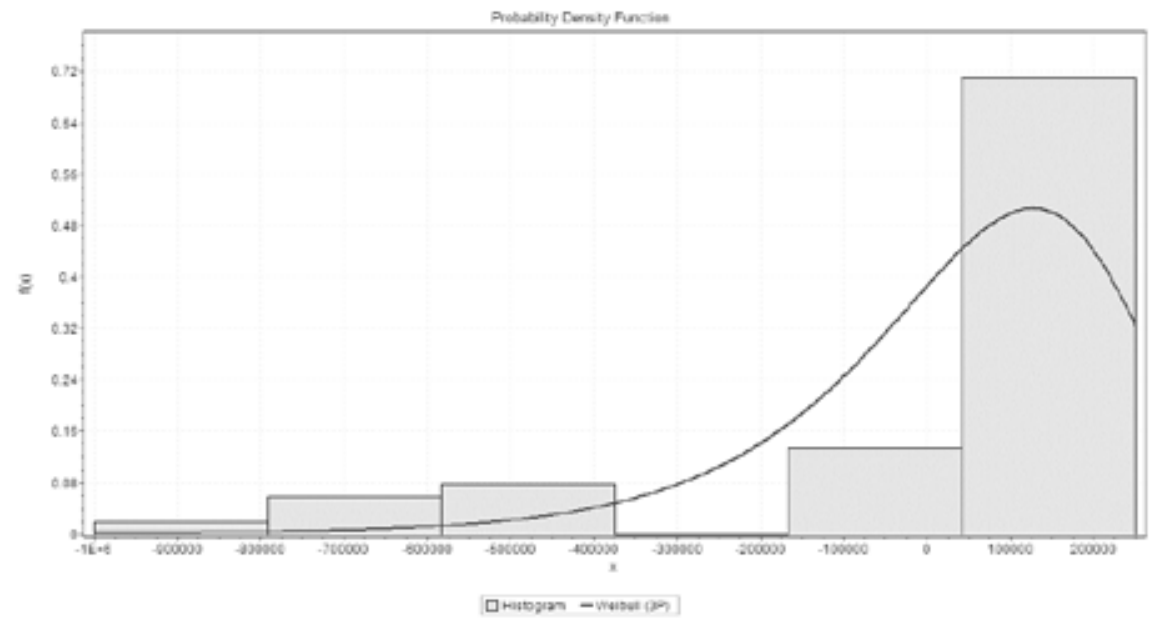

(e)

Sumber: Histogram H asil Simulasi Software Easyfit

G ambar 2

Histogram untuk $T=52$ dengan $A=R p .1 .000 .000$ 


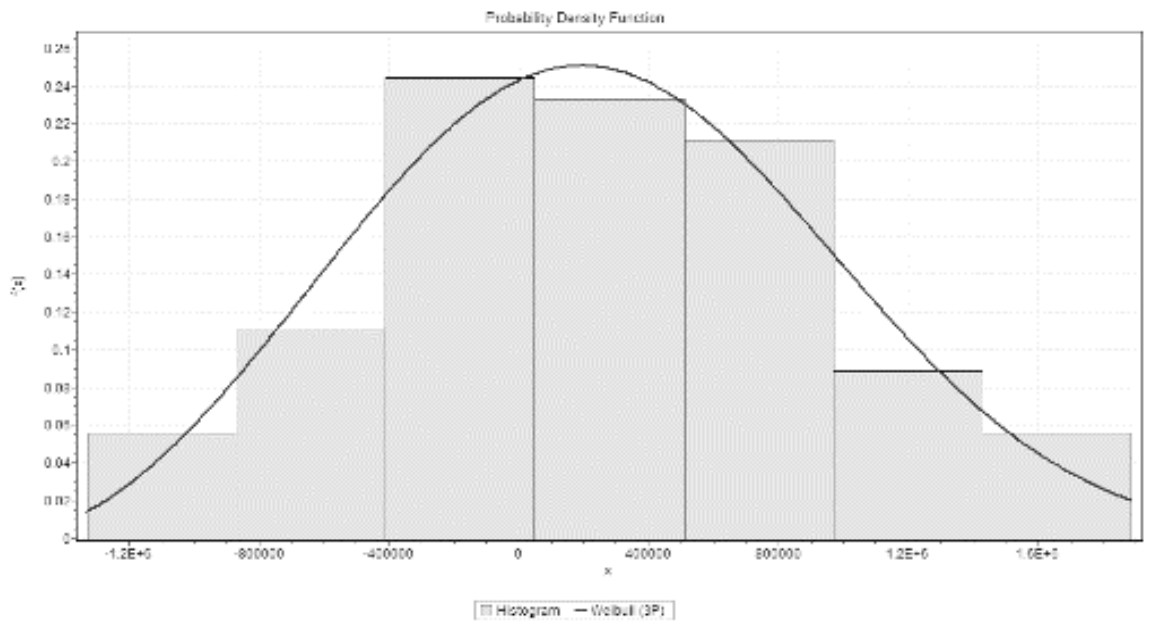

(a)

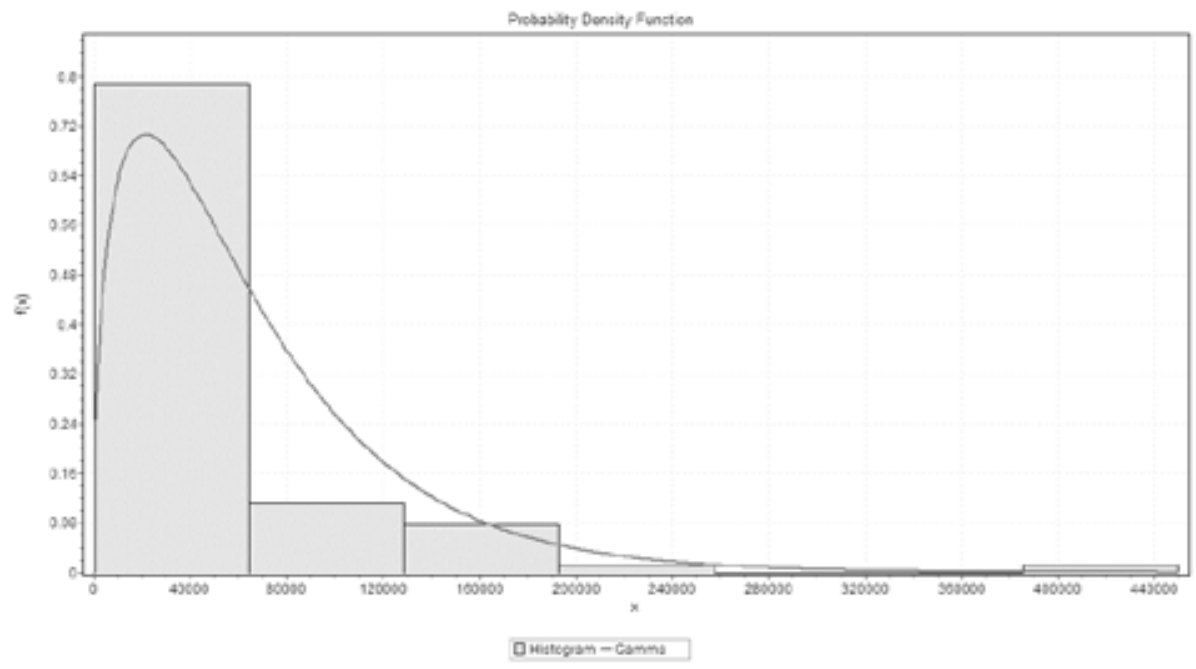

(b)

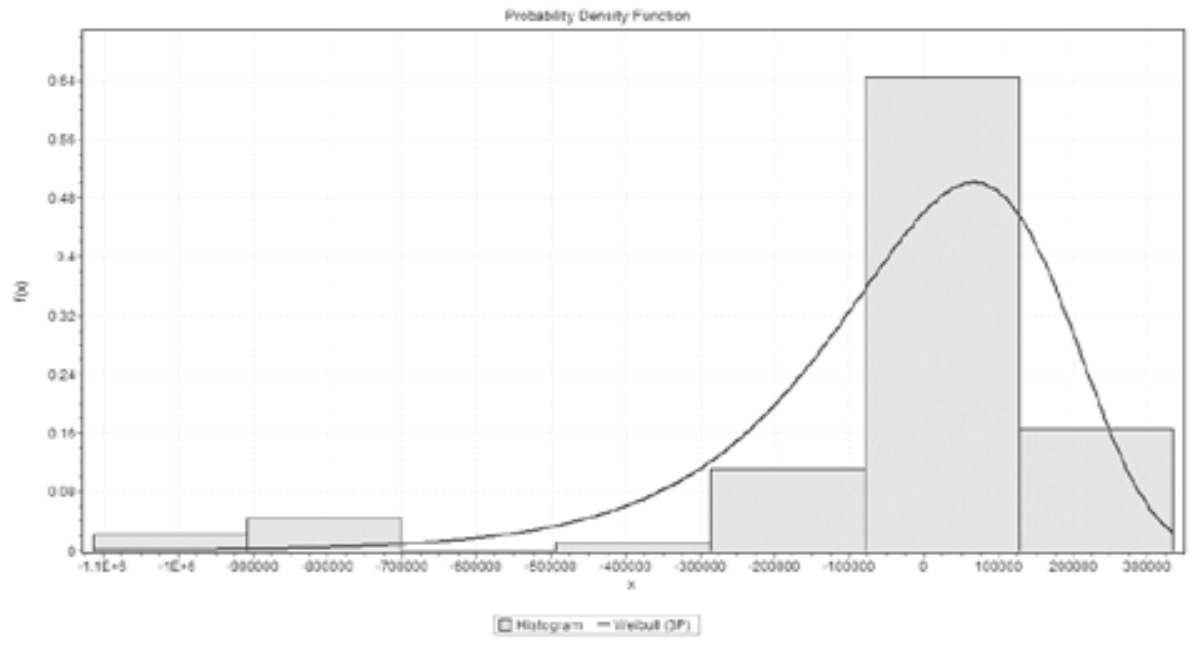

(c) 


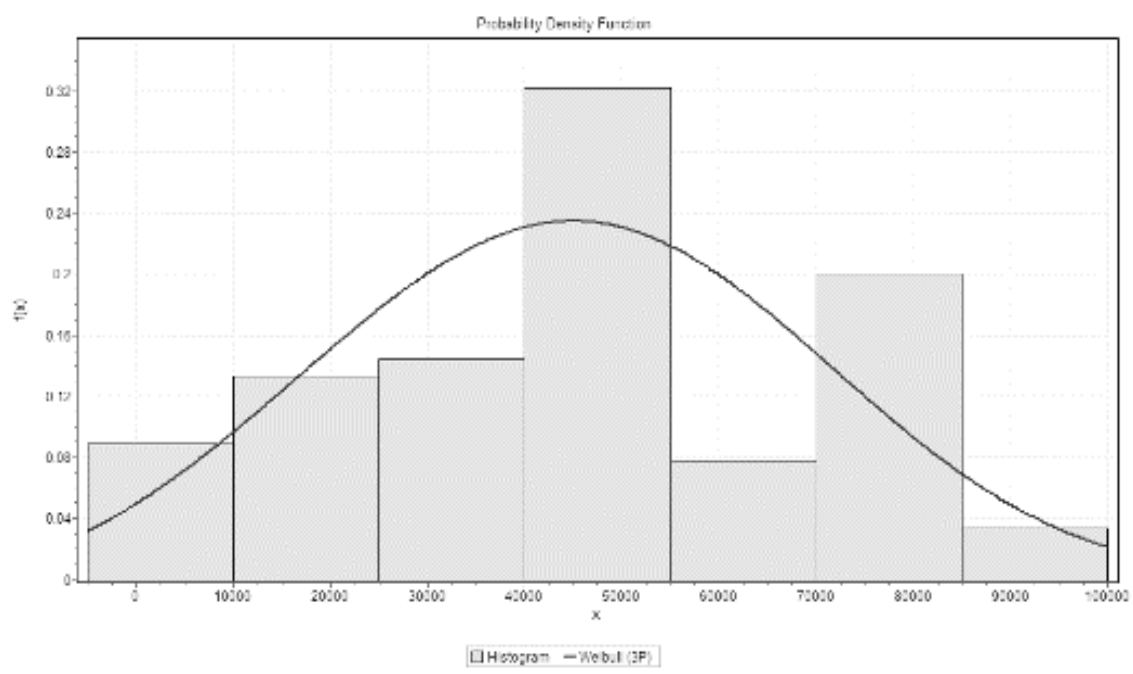

(d)

Sumber: Histogram H asil Simulasi Software Easyfit

\section{G ambar 3}

Histogram untuk $T=90$ dengan $A=R p .1 .000 .000$

Tabel 4

Implementasi model rentenir dengan $A=R p .1 .000 .000$

\begin{tabular}{ccc}
\hline Ped & porped $_{\text {rent }}$ & $\boldsymbol{r}_{\text {rent }}$ \\
\hline & $T=30$ & \\
1 & 0.8438 & 0.0055 \\
2 & 0.2253 & 0.0058 \\
4 & 0.1913 & 0.0057 \\
& $T=52$ & \\
1 & 0.9132 & 0.0035 \\
2 & 0.5822 & 0.0032 \\
4 & 0.2161 & 0.0038 \\
& $T=90$ & \\
1 & 0.9308 & 0.0023 \\
2 & 0.7788 & 0.0019 \\
4 & 0.6764 & 0.0019 \\
\hline
\end{tabular}

Sumber: H asil I mplementasi M odel Rentenir

Tabel 4 merupakan hasil implementasi untuk model rentenir. Hasil ini akan selanjutnya digunakan untuk penentuan porsi bagi hasil optimal untuk model syari'ah. Berdasarkan langkah-langkah yang dijelaskan untuk menentukan porsi bagi hasil optimal maka didapat sifat-sifat untuk setiap model keoptimalan sebagai berikut:
Model Keoptimalan 1

Untuk porsi bagi hasil yang sama diketahui bahwa semakin besar $\alpha$ maka nilai fungsi objektif semakin kecil, sedangkan untuk $\alpha$ yang sama diketahui bahwa semakin besar porsi bagi hasil maka nilai fungsi objektif akan mengecil pada $\alpha=$ $0,1, \ldots, 0.3$ membentuk parabola pada $\alpha=$ $0,4, \ldots, 0,5$ dan akan membesar pada sisa $\alpha$ selanjutnya.

\section{Model Keoptimalan 2}

Untuk porsi bagi hasil yang sama diketahui bahwa semakin besar $\alpha$ maka nilai fungsi objektif semakin kecil sedangkan untuk nilai $\alpha$ yang sama diketahu bahwa semakin besar porsi bagi hasil maka nilai fungsi objektif akan membesar.

\section{Model Keoptimalan 3}

Untuk porsi bagi hasil yang sama diketahui bahwa semakin besar $\alpha$ maka nilai fungsi objektif semakin kecil dan nilai $k$ semakin besar sedangkan untuk $\alpha$ yang sama diketahui bahwa semakin besar porsi bagi hasil maka nilai fungsi objektif mengecil pada $\alpha=0,1, \ldots, 0,9$ dan fluktuatif pada $\alpha=1$ 
Model Keoptimalan 4

Untuk porsi bagi hasil yang sama diketahui bahwa semakin besar $\alpha$ maka nilai fungsi objektif semakin mengecil dan nilai $k$ semakin besar sedangkan untuk $\alpha$ yang sama diketahui bahwa semakin besar porsi bagi hasil maka nilai fungsi objektif membesar pada $\alpha=0,1, \ldots, 0,9$ dan fluktuatif di $\alpha=0$.

Disisi lain menurut (Rizal, 2013) menyatakan terdapat tiga jenis keoptimalan dalam laba bersih pedagang, yaitu tipe keoptimal stasioner, tipe keoptimalan di batas bawah dan tipe keoptimalan di batas atas. Berikut penjelasan singkat mengenai tipe keoptimalan ini:

1. Tipe keoptimalan di titik stasioner Misalkan $p_{\min }$ adalah batas bawah selang keoptimalan porsi bagi hasil dan $p_{\max }$ adalah batas atas selang keoptimalan porsi bagi hasil. Tipe keoptimalan ini memberikan porsi bagi hasil pada selang $\left[p_{\min }, p_{\max }\right]$. Gambar 4 merupakan contoh hasil plot untuk tipe ini.

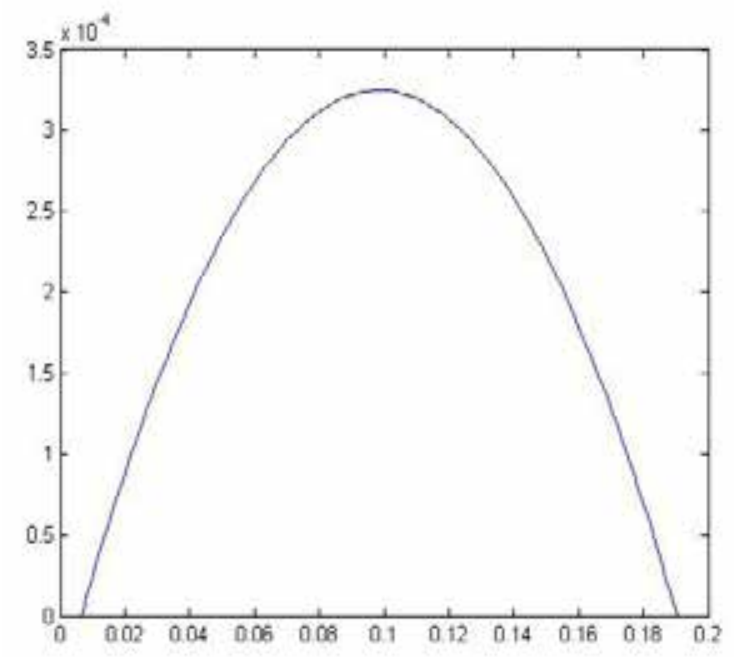

Sumber: Tesis Fitriani, 2014

G ambar 4

Plot $F(p)$ di Titik Stasioner

Tipekeoptimalan ini merupakan tipe keoptimalan porsi bagi hasil yang paling ideal. Hal ini dikarenakan terdapat keseimbangan keuntungan antara pedagang dan investor.
2. Tipekeoptimalan di batas bawah Tipe ini memperlihatkan bahwa investor tidak mendapatkan keuntungan lebih banyak karena maksimum $F(p)$ berada pada porsi bagi hasil yang kecil. $\mathrm{Hal}$ in berarti tidak ada keadilan dalam porsi bagi hasil yang dihasilkan sehingga tipe ini merupakan salah satu tipe yang dihindari dalam proses implementasi.

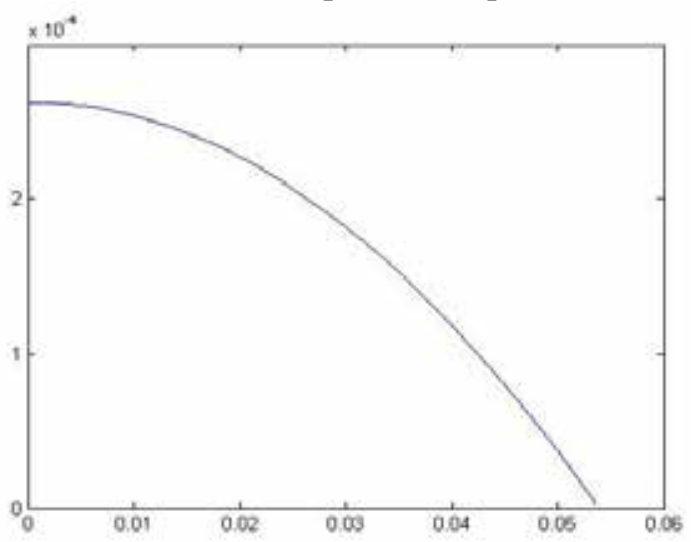

Sumber: Tesis Fitriani, 2014

\section{G ambar 5 \\ Plot $F(p)$ di Batas Bawah}

3. Tipe keoptimalan di batas atas

Tipe ini sama dengan tipe sebelumnya. Pada tipe ini, porsi bagi hasil yang didapat membuat pedagang tidak mendapat pembagian keuntungan yang adil.

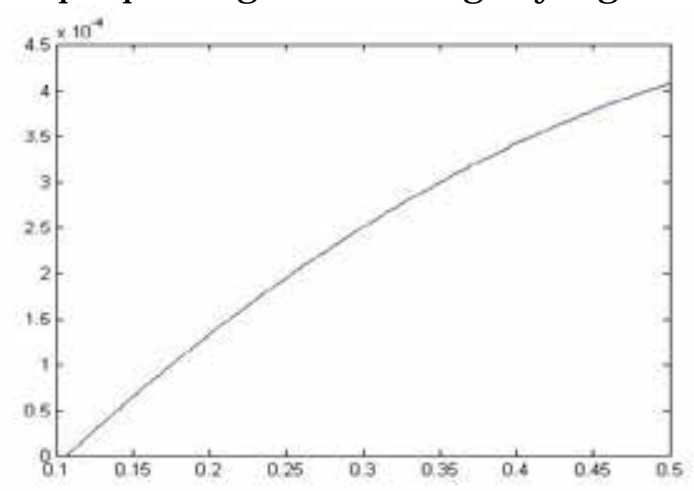

Sumber: Tesis Fitriani, 2014

\section{G ambar 6}

Plot $F(p)$ di Batas A tas

Ketiga tipe keoptimalan di atas ditemukan pada model keoptimalan 1 dengan persamaan [7]. Sesuai dengan sifat yang dimiliki maka dipilih $\alpha=0,4$ meme- 
nuhi tipe keoptimalan di titik stasioner. Oleh karena itu dipilih model keoptimalan 1 sebagai model keoptimalan yang paling ideal untuk model profit-loss sharing pada jurnal ini yang memberi keoptimalan terhadap investor dan pedagang secara seimbang.

Tabel 5 memberikan hasil implementtasi pada model PLS. Berdasarkan nilai $p$ yang didapat dari model keoptimalan 1, maka akan ditentukan porped $d_{\text {syar }+ \text { tab }}$ dan $r_{\text {syar }+t a b}$. Penambahan $Q(t)$ pada model PLS dimulai dengan menentukan $\overline{P r}$ untuk setiap pedagang. Variabel $\overline{P r}$ merupakan nilai rata-rata premi dari 1000 data bangkitan. Proses ini dilakukan dengan menggunakan persamaan sisa dana tabarru dimana untuk $S D T=0$ maka $\mathrm{Pr}$ memenuhi persamaan sebagai berikut:

$$
\operatorname{Pr}=\frac{\sum_{i=0}^{T} a_{i}\left(1+r_{B I}\right)^{T-i}}{\sum_{i=0}^{T} b_{i}\left(1+r_{B I}\right)^{T-i}}
$$

Dengan menggunakan 1000 simulasi data bangkitan maka dapat ditentukan $\overline{P r}$. Hasil simulasi diberikan pada Tabel 6.

Tabel 5

Implementasi model PLS

dengan $A=R p .1 .000 .000$

\begin{tabular}{cccc}
\hline \hline Ped & porped $_{\text {syar }}$ & $\boldsymbol{r}_{\text {syar }}$ & $\boldsymbol{p}$ \\
\multicolumn{4}{c}{$T=30$} \\
1 & 0.8832 & 0.0017 & 0.0026 \\
2 & 0.4028 & 0.0019 & 0.0290 \\
4 & 0.3723 & 0.0013 & 0.0251 \\
\multicolumn{4}{c}{$T=52$} \\
1 & 0.9479 & 0.0015 & 0.0017 \\
2 & 0.6617 & 0.0017 & 0.0145 \\
4 & 0.6588 & 0.0012 & 0.0134 \\
\multicolumn{4}{c}{$T=90$} \\
1 & 0.9516 & 0.0007 & 0.0011 \\
2 & 0.8255 & 0.0008 & 0.0061 \\
4 & 0.7448 & 0.0008 & 0.0092 \\
\hline
\end{tabular}

Sumber: H asil I mplementasi M odel PLS

Premi pada hasil ini disebut premi individu karena hanya berlaku pada masing-masing pedagang saja. Berdasarkan hasil ini, implementasi dilanjutkan pada model PLS dengan penambahan dana tabarru'.

Tabel 6

$\overline{\operatorname{Pr}}$ dengan $A=R p .1 .000 .000,00$

\begin{tabular}{cccc}
\hline \hline Ped & $\overline{\boldsymbol{P r}}_{\boldsymbol{T}=\mathbf{3 0}}$ & $\overline{\boldsymbol{P r}}_{\boldsymbol{T}=\mathbf{5 2}}$ & $\overline{\boldsymbol{P r}}_{\boldsymbol{T}=\mathbf{9 0}}$ \\
\hline 1 & 19402 & 11223 & 2582.40 \\
2 & 1980 & 368.64 & 433.56 \\
3 & 1642.7 & 6.02 & 628.29 \\
\hline
\end{tabular}

Sumber: Hasil Simulasi Perhitungan $\overline{\mathbf{P r}}$

Sama dengan implemensi model PLS, penambahan $Q(t)$ juga dilakukan pada variasi lama periode yang sama. Tabel 7 memberikan hasil implementasi model PLS dengan penambahan $Q(t)$. Terlihat disini bahwa profit yang didapat untuk pedagang lebih besar daripada profit pada model sebelumnya. Hal ini menunjukkan bahwa penambahan $Q(t)$ memberikan pengaruh positif bagi model PLS.

Pada model ini, dilakukan perhitungan SDT dengan tujuan memdapatkan premi yang optimal. Sebagaimana yang dijelaskan sebelumnya, pada artikel ini digunakan algoritma genetika dalam proses simulasinya. Hasil simulasi SDT diberikan pada Tabel 8.

Tabel 7

Implementasi model PLS dengan penambahan $Q(t)$ pada $A=R p .1 .000 .000$

\begin{tabular}{ccc}
\hline \hline Ped & porped $_{\text {rent }}$ & $\boldsymbol{r}_{\text {rent }}$ \\
\hline & $T=30$ & \\
1 & 0.9025 & 0.0023 \\
2 & 0.4196 & 0.0016 \\
4 & 0.3232 & 0.0011 \\
& $T=52$ & \\
1 & 0.9516 & 0.0017 \\
2 & 0.6848 & 0.0012 \\
4 & 0.6754 & 0.0011 \\
& $T=90$ & \\
1 & 0.9666 & 0.0011 \\
2 & 0.8381 & 0.0007 \\
4 & 0.7779 & 0.0007 \\
\hline
\end{tabular}

Sumber: Hasil Implementasi Model PLS dengan penambahan dana tabarru' 
Tabel 8

Hasil simulasi $S D T$ dan $a$ dengan $A=R p .1 .000 .000$

\begin{tabular}{ccc}
\hline Ped & $\boldsymbol{a}$ & $\boldsymbol{S D T}$ \\
\hline & $T=30$ & \\
1 & 2.4442 & 0.0220 \\
2 & 0.5866 & 0.0124 \\
4 & 1.9078 & 0.0437 \\
& $T=52$ & \\
1 & 0.9615 & 0.0692 \\
2 & 0 & 0 \\
4 & 0 & 0 \\
& $T=90$ & \\
1 & 2.4422 & 0.0097 \\
2 & 1.5769 & 0.0326 \\
4 & 1.3053 & 0.0109 \\
\hline
\end{tabular}

Sumber: Hasil Simulasi Pehitungan $S D T$

Berdasarkan Tabel 8 dapat disimpulkan premi optimal untuk setiap pedagang. Misalkan untuk periode investasi $T=30$ didapat bahwa pedagang 1 memiliki $S D T=$ 0,0220 , yang artinya hubungan antara pembayaran $\mathrm{Pr}$ dengan $b$ yang diberikan sudah seimbang, dengan pengali premi sebesar $a=2,4442$.

\section{Implementasi V ariasi Jumlah Investasi}

Diketahui sebelumnya bahwa variasi periode investasi memberikan profit yang optimal seiring dengan bertambahnya lama periodeinvestasi $T$, sehingga akan dilakukan implementasi dengan variasi jumlah investasi. Variasi jumlah investasi didasarkan pada $\bar{w}$ untuk setiap pedagang. Dengan menggunakan hasil pada Tabel 2 maka didefinisikan $A^{*}$ yang merupakan jumlah investasi baru yang memenuhi persamaan sebagai berikut:

$A^{*}=k \times \bar{w} \times T$ dengan $k=\frac{1}{4}, \frac{1}{2}, \frac{3}{4}$

Konstanta $k$ merupakan pengali pada $A^{*}$ yang dipilih sebelumnya dan $T$ merupakan lama periode untuk setiap investasi. Setelah mendapatkan $A^{*}$ selanjutnya dilakukan simulasi sesuai model investasi yang dikaji. Tabel 9 memberikan hasil dari implementasi variasi $A^{*}$ pada model investasi pada $T=52$.
Berdasarkan Tabel 9 disimpulkan bahwa variasi jumlah investasi memberikan profit yang semakin kecil seiring dengan bertambanya jumlah investasi untuk lama periode yang sama. Hal ini dikarena meningkatnya angsuran pokok seiring dengan meningkatnya nilai $A^{*}$ sehingga pedagang akan merasa keberatan dalam proses pelunasan jika laba bersih yang didapat sama, oleh karena itu diperlukan modifikasi bangkitan sesuai dengan jumlah dan periode investasi. Modifikasi pembangkitan data laba bersih dimulai dengan melakukan pemahaman terhadap distribusi dan parameter setiap data pedagang. Terdapat 2 distribusi dalam artikel ini, yaitu: distribusi Weibull dan gamma. Distribusi Weibull diperkenalkan oleh fisikawan Swedia, Waloddi Weibull, pada 1939 (Ronald Walpole, 1995).

\section{Tabel 9}

H asil simulasi dengan variasi jumlah dan periode investasi pada $T=52$

\begin{tabular}{cccc}
\hline \hline \multicolumn{4}{c}{ Pedagang 1 dengan $\overline{\boldsymbol{w}}=\mathbf{3 6 3 1 1 3 . 4 6}$} \\
\hline & $k=0.25$ & $k=0.5$ & $k=0.75$ \\
porped $_{\text {rent }}$ & 0.7633 & 0.5289 & 0.3072 \\
$r_{\text {rent }}$ & 0.0041 & 0.004 & 0.004 \\
$p$ & 0.013 & 0.033 & 0.073 \\
porped $_{\text {syar }}$ & 0.8781 & 0.6158 & 0.4279 \\
$r_{\text {syar }}$ & 0.002 & 0.0019 & 0.0021 \\
$\overline{P r}$ & 51527 & 168620 & 242820 \\
porped $_{\text {syar }+ \text { tab }}$ & 0.7933 & 0.5543 & 0.4126 \\
$r_{\text {syar }+ \text { tab }}$ & 0.0132 & 0.0174 & 0.0138 \\
SDT & 0.0013 & 0.0068 & 0.0073 \\
$a$ & 0.9427 & 0.7683 & 1.1159
\end{tabular}

\begin{tabular}{|c|c|c|c|}
\hline \multicolumn{4}{|c|}{ Pedagang 2 dengan $\bar{w}=59655.02$} \\
\hline porped $_{\text {rent }}$ & 0.675 & 0.35 & 0.025 \\
\hline$r_{\text {rent }}$ & 0.0041 & 0.0041 & 0.0041 \\
\hline$p$ & 0.018 & 0.054 & 0.162 \\
\hline porped $_{\text {syar }}$ & 0.7365 & 0.473 & 0.2095 \\
\hline$r_{\text {syar }}$ & 0.002 & 0.002 & 0.002 \\
\hline$\overline{P r}$ & 136.05 & 1984.6 & 9455.6 \\
\hline orped $_{\text {syar }+t a b}$ & 0.7727 & 0.5102 & 0.2546 \\
\hline$r_{\text {syar }+t a b}$ & 0.0024 & 0.0026 & 0.0014 \\
\hline$S D T$ & 0 & 0 & 0 \\
\hline$a$ & 0 & 0 & 0 \\
\hline
\end{tabular}




\begin{tabular}{cccc}
\multicolumn{4}{c}{ Pedagang 4 dengan $\overline{\boldsymbol{w}}=\mathbf{5 4 9 5 0 . 4 6}$} \\
porped $_{\text {rent }}$ & 0.6751 & 0.346 & 0.0499 \\
$r_{\text {rent }}$ & 0.0041 & 0.0043 & 0.0045 \\
$p$ & 0.01 & 0.051 & 0.16 \\
porped $_{\text {syar }}$ & 0.7425 & 0.4746 & 0.2086 \\
$r_{\text {syar }}$ & 0.0011 & 0.0018 & 0.002 \\
$\overline{P r}$ & 0 & 254.01 & 1669.2 \\
porped $_{\text {syar }+ \text { tab }}$ & 0.7426 & 0.4726 & 0.2346 \\
$r_{\text {syar }+ \text { tab }}$ & 0.0011 & 0.0022 & 0.0034 \\
$S D T$ & 0 & 0.0033 & 0.0048 \\
$a$ & 0 & 2.2730 & 2.312
\end{tabular}

Sumber: Hasil Implementasi Model PLS dengan penambahan dana tabarru' pada variasi jumlah investasi

Parameter dalam distribusi ini antara lain: $\alpha$ adalah parameter bentuk, $\beta$ adalah parameter skala dan $\gamma$ adalah parameter lokasi. Parameter $\gamma$ menunjukkan lokasi kurva dimulai sehingga $-\infty<\gamma<\infty$, sedangkan untuk distibusi gamma merupakan distribusi yang didasari oleh fungsi gamma. Parameter dalam distribusi ini sama dengan parameter yang dimiliki distribusi Weibull. Kedua distribusi ini menggunakan parameter bentuk, skala dan lokasi maka modifikasi bangkitan dilakukan dengan memberikan pengali parameter $p p$ pada parameter skala dan lokasi saja. Persamaan yang digunakan untuk $p p$ adalah:

$$
p p=\frac{3}{4} \times \frac{A^{*}}{A}
$$

dengan $A=R p .1 .000 .000$

Konstanta $\frac{3}{4}$ ditambahkan pada persamaan di atas dengan asumsi bahwa perolehan $w(t)$ tidak bertambah sama persis dengan perolehan $A^{*}$. Misalkan $A^{*}$ dikalikan 2 maka $w(t)$ yang didapat tidak sama persis dengan $2 w(t)$ yang didapat sebelumnya. Dengan kata lain, selalu ada factor yang mempengaruhi perolehan lama bersih pedagang setiap harinya.

Setelah melakukan modifikasi data bangkitan maka implementasi dilakukan yang selanjutnya dilakukan perhitungan profit untuk pedagang dan investor seperti model PLS sebelumnya. Tabel 10, 11 dan 12 memberikan hasil simulasi dengan variasi jumlah dan periode investasi. Dari ketiga tabel dapat terlihat hubungan antara data dengan variasi jumlah dan periode investasi.

Variasi jumlah investasi tidak memberikan perubahan profit yang signifikan untuk lama periode yang sama. Hal ini dikarenakan, seiring bertambahnya jumlah investasi maka bertambah pula kewajiban pedagang untuk melunasi iuran pokok pada periode tertentu yang tentu saja lebih memberatkan.

Secara umum benar jika semakin banyak modal tambahan maka pedagang dapat membeli barang lebih banyak untuk diperjualbelikan namun terdapat iuran pokok yang juga mempengaruhi besar profit yang diterima pedagang, sedangkan untuk variasi periode memberikan simpulan berbeda. Semakin bertambahnya periode investasi maka semakin menguntungkan bagi pedagang untuk jumlah periode yang sama.

Tabel 10

H asil simulasi dengan variasi jumlah dan periode investasi pedagang 1

\begin{tabular}{cccc}
\hline \hline & $\boldsymbol{T}=\mathbf{3 0}$ & & \\
\hline porped $_{\text {rent }}$ & $k=0.25$ & $k=0.5$ & $k=0.75$ \\
$r_{\text {rent }}$ & 0.8865 & 0.8827 & 0.8150 \\
$p$ & 0.0053 & 0.0052 & 0.0052 \\
porped $_{\text {syar }}$ & 0.9106 & 0.003 & 0.002 \\
$r_{\text {syar }}$ & 0.0016 & 0.0016 & 0.8538 \\
porped $_{\text {syar+tab }}$ & 0.9098 & 0.9009 & 0.9284 \\
$r_{\text {syar+tab }}$ & 0.0019 & 0.0019 & 0.0017 \\
SDT & 0.0054 & 0.0056 & 0.0059 \\
$a$ & 0.761 & 1.1433 & 1.4346 \\
& $\mathbf{T}=\mathbf{5 2}$ & & \\
porped $_{\text {rent }}$ & 0.8909 & 0.8996 & 0.9133 \\
$r_{\text {rent }}$ & 0.0031 & 0.0031 & 0.0031 \\
$p$ & 0.002 & 0.002 & 0.002 \\
porped $_{\text {syar }}$ & 0.9135 & 0.9203 & 0.9309 \\
$r_{\text {syar }}$ & 0.0013 & 0.0012 & 0.0014 \\
porped $_{\text {syar }+ \text { tab }}$ & 0.9319 & 0.9473 & 0.9376 \\
$r_{\text {syar+tab }}$ & 0.0013 & 0.0015 & 0.0014 \\
SDT $_{\text {a }}$ & 0.0089 & 0.0034 & 0.0087 \\
$a$ & 0.6817 & 1.0955 & 1.1504
\end{tabular}




$\begin{array}{cccc} & \boldsymbol{T}=\mathbf{9 0} & & \\ \text { porped }_{\text {rent }} & 0.9384 & 0.9289 & 0.9381 \\ r_{\text {rent }} & 0.0019 & 0.0018 & 0.0018 \\ p & 0.002 & 0.003 & 0.002 \\ \text { porped }_{\text {syar }} & 0.9513 & 0.944 & 0.9509 \\ r_{\text {syar }} & 0.0007 & 0.0006 & 0.0007 \\ \text { porped }_{\text {syar }+ \text { tab }} & 1.0238 & 1.0229 & 1.0244 \\ r_{\text {syar }+ \text { tab }} & 8.11 \mathrm{e}-6 & 6.9 \mathrm{e}-6 & 1.2 \mathrm{e}-5 \\ \text { SDT } & 0.0018 & 0.006 & 0.002 \\ a & 0.8594 & 1.2168 & 1.0113\end{array}$

Sumber: H asil I mplementasi Pedagang 1 pada M odel PLS dengan Penambahan D ana Tabarru' pada variasi jumlah dan periode investasi

Tabel 11

Hasil simulasi dengan variasi jumlah dan periode investasi pedagang 2

\begin{tabular}{cccc}
\hline \hline & $\boldsymbol{T}=\mathbf{3 0}$ & & \\
\hline & $k=0.25$ & $k=0.5$ & $k=0.75$ \\
porped $_{\text {rent }}$ & -0.037 & -0.044 & -0.027 \\
$r_{\text {rent }}$ & 0.0071 & 0.0063 & 0.0058 \\
$p$ & 0.001 & 0.009 & 0.001 \\
porped $_{\text {syar }}$ & 0.2317 & 0.2095 & 0.2160 \\
$r_{\text {syar }}$ & 0.0005 & 0.0004 & 0.0005 \\
porped $_{\text {syar+tab }}$ & 0.2957 & 0.2623 & 0.2651 \\
$r_{\text {syartab }}$ & 0.0009 & 0.0009 & 0.0008 \\
SDT & 0.0082 & 0.0094 & 0.0031 \\
$a$ & 1.2535 & 0.59 & 1.6374 \\
& $\mathbf{T}=\mathbf{5 2}$ & & \\
porped $_{\text {rent }}$ & 0.4289 & 0.404 & 0.4571 \\
$r_{\text {rent }}$ & 0.0033 & 0.0033 & 0.0032 \\
$p$ & 0.023 & 0.025 & 0.021 \\
porped $_{\text {syar }}$ & 0.5474 & 0.5276 & 0.569 \\
$r_{\text {syar }}$ & 0.0014 & 0.0014 & 0.0014 \\
porped $_{\text {syar }+ \text { tab }}$ & 0.5621 & 0.6011 & 0.6080 \\
$r_{\text {syar }+ \text { tab }}$ & 0.0007 & 0.0008 & 0.0008 \\
SDT & 0.0023 & 0.0055 & 0.0048 \\
$a$ & 0.2931 & 0.9543 & 0.7559 \\
& $\boldsymbol{T}=\mathbf{9 0}$ & & \\
porped $_{\text {rent }}$ & 0.648 & 0.6631 & 0.7073 \\
$r_{\text {rent }}$ & 0.0021 & 0.0022 & 0.0021 \\
$p$ & 0.012 & 0.012 & 0.009 \\
porped $_{\text {syar }}$ & 0.7209 & 0.7334 & 0.7684 \\
$r_{\text {syar }}$ & 0.0009 & 0.0009 & 0.0009 \\
porped $_{\text {syar }+ \text { tab }}$ & 0.7964 & 0.8080 & 0.8049 \\
$r_{\text {syar }+ \text { tab }}$ & 0.0005 & 0.0006 & 0.0005 \\
SDT & 0.0048 & $9.0 \mathrm{e}-4$ & 0.002 \\
$a$ & 0.9242 & 0.811 & 1.1095 \\
\hline & & & \\
\hline
\end{tabular}

Sumber: Hasil I mplementasi Pedagang 2 pada M odel PLS dengan Penambahan Dana Tabarru' pada variasi jumlah dan periode investasi

Tabel 12

Hasil simulasi dengan variasi jumlah dan periode investasi pedagang 4

\begin{tabular}{|c|c|c|c|}
\hline \multicolumn{4}{|c|}{$T=30$} \\
\hline & $k=0.25$ & $k=0.5$ & $k=0.75$ \\
\hline porped $_{\text {rent }}$ & -0.117 & -0.072 & 0.057 \\
\hline$r_{\text {rent }}$ & 0.0076 & 0.0063 & 0.0057 \\
\hline$p$ & 0.006 & 0.008 & 0.0011 \\
\hline porped $_{\text {syar }}$ & 0.1755 & 0.1892 & 0.2301 \\
\hline & 0.0003 & 0.0004 & 0.0005 \\
\hline porped $_{\text {syar }+t o}$ & 0.1801 & 0.1828 & 0.2167 \\
\hline$r_{\text {syar }+t a b}$ & 0.0004 & 0.0004 & 0.0005 \\
\hline$S D^{\prime}$ & 0.0087 & 0.006 & 0.0072 \\
\hline$a$ & $\begin{array}{c}0.9602 \\
T=52\end{array}$ & 1.087 & 0.7668 \\
\hline porped $_{\text {rent }}$ & 0.4177 & 0.4259 & 0.4235 \\
\hline$r_{\text {rent }}$ & 0.0032 & 0.0031 & 0.0031 \\
\hline & 0.023 & 0.021 & 0.022 \\
\hline porped $_{\text {syar }}$ & 0.5379 & 0.5439 & 0.5419 \\
\hline & 0.0013 & 0.0013 & 0.0012 \\
\hline porped $_{\text {syar }+t}$ & 0.5673 & 0.5505 & 0.5579 \\
\hline$r_{\text {syar }+t a b}$ & 0.0006 & 0.0006 & 0.0006 \\
\hline$S D T$ & 0.0013 & 0.0093 & 0.0052 \\
\hline$a$ & $\begin{array}{l}2.9935 \\
T=90\end{array}$ & 0.7249 & 0.4535 \\
\hline porped $_{\text {rent }}$ & 0.6167 & 0.6335 & 0.6126 \\
\hline$r_{\text {rent }}$ & 0.0019 & 0.0019 & 0.0018 \\
\hline$p$ & 0.012 & 0.01 & 0.011 \\
\hline porped $_{\text {syar }}$ & 0.695 & 0.7082 & 0.6915 \\
\hline & 0.0009 & 0.0008 & 0.0008 \\
\hline porped $_{\text {syar }+t}$ & 0.6872 & 0.7018 & 0.7117 \\
\hline$r_{\text {syar }+t a b}$ & & 0.0004 & 0.0005 \\
\hline$S D T$ & 0.0066 & 0.0028 & 0.0016 \\
\hline 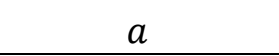 & 1.619 & 0.9996 & 1.2553 \\
\hline
\end{tabular}

Sumber: Hasil I mplementasi Pedagang 4 pada M odel PLS dengan Penambahan D ana Tabarru' pada variasi jumlah dan periode investasi

\section{SIMPULAN DAN SARAN \\ Simpulan}

Model PLS merupakan model investasi yang efektif dalam penyelesaian permasalahan mengenai praktek riba dalam bidang keuangan masyarakat. Model ini dapat digunakan sebagai salah satu pilihan 
untuk melakukan transaksi keuangan yang sesuai dengan syariat Islam. Masyarakat khususnya pedagang kecil dapat memulai menggunakan model PLS dan meninggalkan praktek rentenir.

Penambahan dana tabarru' pada model PLS, dengan memberikan modal tambahan pada pedagang di Pasar Balubur Bandung, memberikan profit yang lebih tinggi bagi investor dan pedagang untuk lama periode investasi yang sama. Variasi jumlah dan lama periode investasi berpengaruh pada profit yang didapat dari model ini. Jumlah investasi yang berbeda menghasilkan profit yang cenderung sama jika dilakukan pada lama periode yang sama, sedangkan, variasi lama periode menghasilkan profit pedagang yang semakin besar seiring bertambahnya periode namun investor mendapatkan profit yang cenderung turun sei ring bertambahnya lama periode.

\section{Saran}

Dalam penelitian ini terdapat beberapa kendala dalam prosesnya, antara lain; jumlah data untuk setiap pedagang yang cenderung sedikit sehingga distribusi yang dihasilkan cenderung tidak stabil dan akurat. Hal ini dikarenakan tidak semua pedagang kooperatif dalam proses pengambilan data selain itu penggunaan 5 pedagang dalam satu lokasi pasar dirasa belum cukup untuk mewakili seluruh pedagang di Indonesia. Berdasarkan pada kendala inilah, maka pada kajian berikutnya diperlukan pengambilan data yang lebih banyak dan variatif sehingga sifat-sifat data akan lebih konsisten terbaca terutama dalam penentuan distribusi dalam proses pembangkitan. Selain itu guna hasil yang lebih optimal diperlukan simulasi dengan menggunakan variansi yang lebih beragam baik dalam hal jumlah maupun periode investasi.

\section{DAFTAR PUSTAKA}

A bdul-Rahman, A., R. L. Abdul dan A. M. Azmi. 2014. Failure and Potential of Profit Loss Sharing Contracts: A
Perspective of N ew Institutional. Science Direct.

Ascarya. 2009. The Lack of Profit Loss Sharing in Indonesia's Islamic Banks: revisited. Centre of Education and Central Banking Studies, Bank Indonesia.

Dar, H. A. and J. R. Presley. 2000. Lack of Profit Loss Sharing in Islamic Banking: Management and Control Imbalance. E con omic R esearch Paper N 0. 00/24.

Direktorat Perbankan Syari'ah. 2011. O utl ook Perbandan Syari'ah Indonesia. Bank Indonesia. Jakarta.

Fitriani. 2014. Simulasi Model Profit and Loss Sharing pada Investasi Syari'ah dengan Penambahan Dana Tabarru' pada Prinsip Musyarakah. Tesis. Program Paska Sarjana Matematika ITB. Bandung.

Gerber, H. U. 1997. Life Insurance M athematics third E dition. Springer. Berlin.

Fitriyani, M, V. 2012. Simulasi Model Bagi Hasil pada Investasi Syari'ah. Skripsi. ITB. Bandung.

Higham, D. J. 2004. An Intoduction to Finantial Option Valuation. Cambridge University Press. N ew York.

Muda, R. B., G. Ismail., G. Abdul dan S. Shahimi. 2011. Profit-Loss Sharing and Economic Value added in Islamic Banking Model. W orking Paper in Islamic E conomics and Finance N 0. 1105.

Mustika, T. 2013. Penentuan Fungsi Objektif pada Masalah Optimasi Porsi Bagi Hasil dalam Investasi Syari'ah. Skripsi. Bandung: ITB.

Pontjowinoto, I. P. 2003. Prinsip Syari'ah di Pasar M odal (Pandangan Praktisi). Modal Publications. Jakarta.

Pusat Riset dan Edukasi Bank Sentral. 2012. Kodifikasi Peraturan Bank IndonesiaLiabilitas dan M odal Pelaksanaan Prinsip Syari'ah dalam Kegiatan Penghimpunan dan Penyaluran Dana Serta Pelayanan Jasa Syari'ah, Produk Bank Syari'ah dan U nit U saha Syari'ah. Bank Indonesia. Jakarta.

Rizal, A. 2013. Simulasi Data dan Pe nentuan Besar Pinjaman dalam Model Investasi Pembiayaan Pedagang Kecil. 
Skripsi. ITB. Bandung.

Samuelson, P. A. dan D. N. William D. 2004. IImu M akroekonomi. Edisi Ketujuh- belas. PT. Media Global Edukasi. Jakarta.

Sugema, I., T. Bakhtiar dan J. Effendi. 2010. Interest Versus Profit-Loss Sharing Credit Contract: Efficiency and Walfare Implications. International Research Journal of Finance an E conomics (45).

Sumarti, N., V. Fitriyani, dan M. Damayanti. 2014. A Mathematical Model of The Profit-Loss Sharing (PLS) Scheme. Science D irect Elsevier Ltd Procedia - Social and Behavioral Sciences 115: 131-137.

Sumarti, N. 2015. Some Problems on Making of Mathematical Modelling of Profit-
Loss Sharing Using Data Simulation. J. $M$ ath. Fund. Sci. 47(1): 1-11.

Suyanto. 2005. Algoritma Genetika dalam M atlab. ANDI Yogyakarta.

Syula, M. S. 2004. A suransi Syari'ah (Life and General). Jakarta: Gema Insani Press.

Walpole, R. E. 1995. IImu Peluang dan Statistika untuk Insinyur dan IImuwan. ITB. Bandung.

Scot, W. F. 1999. Life A ssurance M athematics. Institute of Actuaries. London.

www. mathwave.com. Diakses pada tanggal 31 januari 2015

www.mathw ork.com. Diakses pada tanggal 22 Juni 2015

www.weibull.com. Diakses pada tanggal 9 Juli 2015. 